\title{
Chemical characterization of aerosols at the summit of Mountain Tai in Central East China
}

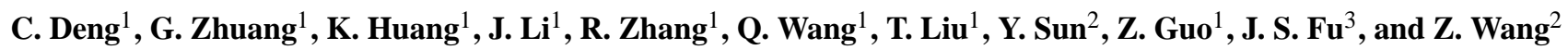 \\ ${ }^{1}$ The Center for Atmospheric Chemistry Study, Department of Environmental Science \& Engineering, Fudan University, \\ Shanghai 200433, China \\ ${ }^{2}$ The Institute of Atmospheric Physics, Chinese Academy of Science, LAPC, Beijing 100029, China \\ ${ }^{3}$ Department of Civil and Environmental Engineering, The University of Tennessee, Knoxville, TN 37996, USA
}

Received: 13 July 2010 - Published in Atmos. Chem. Phys. Discuss.: 2 September 2010

Revised: 18 March 2011 - Accepted: 16 July 2011 - Published: 25 July 2011

\begin{abstract}
PM}_{2.5}$ and TSP samples were collected at the summit of Mountain Tai (MT) (1534 ma.s.1.) in spring 2006/2007 and summer 2006 to investigate the characteristics of aerosols over central eastern China. For comparison, aerosol samples were also collected at Tazhong, Urumqi, and Tianchi in Xinjiang in northwestern China, Duolun and Yulin in northern China, and two urban sites in the megacities, Beijing and Shanghai, in 2007. Daily mass concentrations of TSP and $\mathrm{PM}_{2.5}$ ranged from $39.6-287.6 \mu \mathrm{g} \mathrm{m}^{-3}$ and $17.2-235.7 \mu \mathrm{g} \mathrm{m}^{-3}$ respectively at the summit of MT. Averaged concentrations of $\mathrm{PM}_{2.5}$ showed a pronounced seasonal variation with higher concentration in summer than spring. 17 water-soluble ions $\left(\mathrm{SO}_{4}^{2-}, \mathrm{NO}_{3}^{-}, \mathrm{Cl}^{-}\right.$, $\mathrm{F}^{-}, \mathrm{PO}_{4}^{3-}, \mathrm{NO}_{2}^{-}, \mathrm{CH}_{3} \mathrm{COO}^{-}, \mathrm{CH}_{2} \mathrm{C}_{2} \mathrm{O}_{4}^{2-}, \mathrm{C}_{2} \mathrm{H}_{4} \mathrm{C}_{2} \mathrm{O}_{4}^{2-}$, $\mathrm{HCOO}^{-}, \mathrm{MSA}, \mathrm{C}_{2} \mathrm{O}_{4}^{2-}, \mathrm{NH}_{4}^{+}, \mathrm{Ca}^{2+}, \mathrm{K}^{+}, \mathrm{Mg}^{2+}, \mathrm{Na}^{+}$), and 19 elements of all samples were measured. $\mathrm{SO}_{4}^{2-}, \mathrm{NO}_{3}^{-}$, and $\mathrm{NH}_{4}^{+}$were the major water-soluble species in $\mathrm{PM}_{2.5}$, accounting for $61.50 \%$ and $72.65 \%$ of the total measured ions in spring and summer, respectively. The average ratio of $\mathrm{PM}_{2.5} / \mathrm{TSP}$ was $0.37(2006)$ and 0.49(2007) in spring, while up to 0.91 in summer, suggesting that aerosol particles were primarily comprised of fine particles in summer and of considerable coarse particles in spring. Crustal elements (e.g., $\mathrm{Ca}, \mathrm{Mg}, \mathrm{Al}, \mathrm{Fe}$, etc.) showed higher concentration in spring than summer, while most of the pollution species $\left(\mathrm{SO}_{4}^{2-}, \mathrm{NO}_{3}^{-}, \mathrm{K}^{+}, \mathrm{NO}_{2}^{-}, \mathrm{NH}_{4}^{+}, \mathrm{Cl}^{-}\right.$, organic acids, $\mathrm{Pb}, \mathrm{Zn}, \mathrm{Cd}$, and $\mathrm{Cr}$ ) from local/regional anthropogenic emissions or secondary formation presented higher concentration in summer. The ratio of $\mathrm{Ca} / \mathrm{Al}$ suggested the impact of Asian dust from the western deserts on the air quality in this region.
\end{abstract}

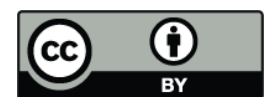

Correspondence to: G. Zhuang

(gzhuang@fudan.edu.cn)
The high concentration of $\mathrm{K}^{+}$in $\mathrm{PM}_{2.5}\left(4.41 \mu \mathrm{g} \mathrm{m}^{-3}\right)$ and its good correlation with black carbon $(r=0.90)$ and oxalic acid $(r=0.87)$ suggested the severe pollution from biomass burning, which was proved to be a main source of fine particles over central eastern China in summer. The contribution of biomass burning to the fine particle at MT accounted for $7.56 \%$ in spring and $36.71 \%$ in summer, and even reached to $81.58 \%$ on a day. As and $\mathrm{Pb}$ were two of the most enriched elements. The long-range transport of aerosols spread the heavy pollution from coal-mining/coal-ash to everywhere over China. Anthropogenic air-pollution was evidently rather severe at MT, though it has been declared by UNESCO to be a World Heritage site.

\section{Introduction}

Aerosols have potential impact on the global atmospheric chemistry, cloud properties and precipitation development (Tegen et al., 1996; Arimoto, 2001; Rastogi and Sarin, 2005, 2006). Anthropogenic aerosols, including the primarily emissions and the secondary aerosols, are mainly in fine mode, which has much more adverse impact on climate and hydrologic cycling (Kaufman et al., 2002), visibility (Chan et al., 1999), and human health (Dockery et al., 1993).

Eastern China, including provinces of Hebei, Shandong, Jiangsu, Zhejiang, and the mega-city, Shanghai, is the area with rapidest growth in economy, e.g. Shandong is one of the two provinces in China, whose GDP exceeded $3 \times 10^{11}$ RMB in 2008 (http://finance.people.com.cn/), which resulted in the increasing emissions of $\mathrm{SO}_{2}, \mathrm{NO}_{2}$, and particulate matter, and, in turn, the severe acidic precipitation (Wang et al., 2008). Mountain Tai $(200 \times 50$ square kilometers $)$, with the highest altitude (1534 $\mathrm{m}$ high) in central-eastern China,

Published by Copernicus Publications on behalf of the European Geosciences Union. 
is located in Shandong and surrounded by Jiangsu, Anhui, Henan, and Hebei provinces. Aerosols, from the summit of MT could be the representative of the regional pollution. Previous study found that $\mathrm{CO}$ and $\mathrm{O}_{3}$ at the top of MT exhibited high in summer and low in winter, which was attributed to the seasonal changes of meteorological conditions and seasonal variations of sources (Gao et al., 2005; Wang et al., 2001). In addition, VOCs, $\mathrm{O}_{3}$, and $\mathrm{CO}$ were all higher than those observed at other rural mountainous sites (Suthawaree, et al., 2010), which might be due to the strong sources surrounded. Average concentration of peroxides at MT was much lower than that measured at some rural mountain sites, suggesting that significant removal processes took place in this region (Ren et al., 2009). $\mathrm{O}_{3}$ and $\mathrm{CO}$ play key roles in determining the oxidizing capacity of the atmosphere in the presence of sunlight, and they are ideal tracers for anthropogenic pollutions (Novelli et al., 1994, 1998). VOC, $\mathrm{O}_{3}, \mathrm{CO}$, and peroxide are all related to the formations of secondary aerosols in ambient air, which suggested that the characteristics of the aerosols at MT might be different from those at other sites.

Mineral aerosols through long-range transport may directly or/and indirectly affect the properties of air mass by providing surfaces for many chemical and physical processes and serving as carriers of anthropogenic substances, which would affect the global climate/environmental change (Guo et al., 2004; Dentener et al., 1996; Sun et al., 2004; Liu et al., 2002). Northwestern China is one of the main source areas of Asian dust that can be transported to hundred and thousand miles away, passing through central and eastern China and even to the Pacific. The composition of mineral aerosols would subject to transform due to adsorbing gaseous species, surface reactions, and coagulation with anthropogenic aerosol on the pathway during transport.

Little information on aerosols at the summit of MT is available. The studies on aerosols reported in literatures mostly represented those samples collected from ground level, and limited knowledge has been acquired on the aerosols at high elevation over the world. MT is just in the downstream of Asian Dust from northwestern China. Therefore, the summit of MT is an ideal site to examine the longrange transport of Asian dust and to observe the mixing of dust with anthropogenic aerosol. This paper presents the characteristics, sources, formation processes, and the relation with the long-range transport of aerosols collected at MT, which would reveal the air quality in PBL (Planetary Boundary Layer) over central east China.

\section{Experimental}

\subsection{Sampling}

TSP and $\mathrm{PM}_{2.5}$ aerosol samples were simultaneously collected at the meteorological observation station located at the summit of MT $\left(36.25^{\circ} \mathrm{N}, 117.10^{\circ} \mathrm{E}\right)$ in spring (14 March-

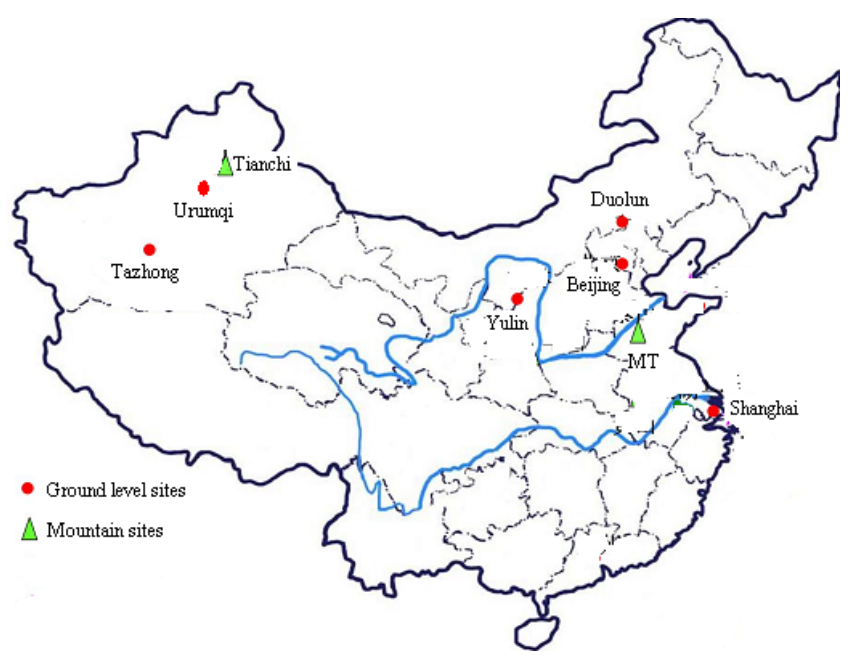

Fig. 1. Map of the sampling sites in this study.

6 May) and summer (2-30 June) in 2006 and in spring (26 March-18 May) in 2007. The sampling duration of each sample was generally $24 \mathrm{~h}$, except a few samples, which was $48 \mathrm{~h}$. All of the samples were collected on Whatman® 41 filters (Whatman Inc., Maidstone, UK) by mediumvolume samplers (model: $\left(\mathrm{TSP} / \mathrm{PM}_{10} / \mathrm{PM}_{2.5}\right.$ )-2, flow rate: $77.59 \mathrm{~L} \mathrm{~min}^{-1}$ ). The samples were put in polyethylene plastic bags right after sampling and reserved in a refrigerator. All of these filters were weighed before and after sampling with an analytical balance (Sartorius 2004MP, reading precision $10 \mu \mathrm{g}$ ) after stabilizing under constant temperature $\left(20 \pm 1{ }^{\circ} \mathrm{C}\right)$ and humidity $(40 \pm 1.5 \%)$ for over $24 \mathrm{~h}$. All the procedures were strictly quality-controlled to avoid any possible contamination of the samples. For comparison, aerosol samples were also collected at Tazhong, Urumqi, Tianchi in Xinjiang in northwestern China, Duolun and Yulin in northern China, and in two urban sites in the megacities, Beijing and Shanghai (Fig. 1). Information of all samples is list in Table 1. The detailed analytical procedures were given elsewhere (Zhuang et al., 2001).

\subsection{Chemical analysis}

\subsubsection{Ion analysis}

One-fourth of each sample and blank filter was extracted ultrasonically by $10 \mathrm{~mL}$ deionized water $\left(18 \mathrm{M} \Omega \mathrm{cm}^{-1}\right)$. After passing through microporous membranes (pore size, $0.45 \mu \mathrm{m}$; diameter, $25 \mathrm{~mm}$; made by the affiliated plant of Beijing chemical school), the filtrates were determined for $\mathrm{pH}$ with a $\mathrm{pH}$ meter (model, Orion 818). Each filtrate was stored at $4^{\circ} \mathrm{C}$ in a clean tube for IC analysis. 12 anions $\left(\mathrm{SO}_{4}^{2-}, \mathrm{NO}_{3}^{-}, \mathrm{Cl}^{-}, \mathrm{F}^{-}, \mathrm{PO}_{4}^{3-}, \mathrm{NO}_{2}^{-}, \mathrm{CH}_{3} \mathrm{COO}^{-}\right.$, $\mathrm{HCOO}^{-}, \mathrm{MSA}, \mathrm{C}_{2} \mathrm{O}_{4}^{2-}, \mathrm{CH}_{2} \mathrm{C}_{2} \mathrm{O}_{4}^{2-}, \mathrm{C}_{2} \mathrm{H}_{4} \mathrm{C}_{2} \mathrm{O}_{4}^{2-}$ ) and 5 cations $\left(\mathrm{NH}_{4}^{+}, \mathrm{Ca}^{2+}, \mathrm{K}^{+}, \mathrm{Mg}^{2+}, \mathrm{Na}^{+}\right)$were analyzed by 
Table 1. Mass concentrations of aerosols $\left(\mu \mathrm{g} \mathrm{m}^{-3}\right)$ at the summit of MT and other sampling sites.

\begin{tabular}{|c|c|c|c|c|c|c|c|c|c|}
\hline \multirow{2}{*}{$\begin{array}{l}\text { Sampling } \\
\text { site }\end{array}$} & \multirow{2}{*}{$\begin{array}{l}\text { Sampling } \\
\text { period }\end{array}$} & \multicolumn{2}{|c|}{ Sample number } & \multicolumn{2}{|c|}{ Average $\left(\mu \mathrm{g} \mathrm{m}^{-3}\right)$} & \multicolumn{2}{|c|}{$\operatorname{Max} .\left(\mu \mathrm{g} \mathrm{m}^{-3}\right)$} & \multicolumn{2}{|c|}{ Min. $\left(\mu \mathrm{g} \mathrm{m}^{-3}\right)$} \\
\hline & & $\mathrm{PM}_{2.5}$ & TSP & $\mathrm{PM}_{2.5}$ & TSP & $\mathrm{PM}_{2.5}$ & TSP & $\mathrm{PM}_{2.5}$ & TSP \\
\hline Tazhong & 20 Mar 2007-19 Apr 2007 & 36 & 35 & 640.4 & 1225.2 & 2295.3 & 5407.4 & 45.3 & 53.3 \\
\hline Tianchi & 2 Apr 2007-2 May 2007 & 31 & 31 & 24 & 57.7 & 117.7 & 191 & 5.3 & 7.3 \\
\hline Duolun & 20 Mar 2007-20 Apr 2007 & 34 & 34 & 64.1 & 176.2 & 590.5 & 1381.7 & 4.3 & 16.7 \\
\hline Yulin & 20 Mar 2007-21 Apr 2007 & 31 & 38 & 83 & 354.4 & 592.1 & 3187 & 7.1 & 25 \\
\hline \multirow[t]{2}{*}{ Beijing } & 21 Mar 2007-20 Apr 2007 & 31 & 31 & 77.1 & 160.9 & 141 & 351.9 & 20.8 & 60.7 \\
\hline & 23 Jul 2007-22 Aug 2007 & 31 & 31 & 78.4 & 114.5 & 129.8 & 261.2 & 10.5 & 78.4 \\
\hline \multirow[t]{2}{*}{ Urumqi } & 19 Mar 2007-19 Apr 2007 & 37 & 37 & 81.9 & 232.5 & 158.9 & 523.8 & 27.7 & 54.5 \\
\hline & 20 Jul 2007-22 Aug 2007 & 34 & 34 & 45.9 & 172.6 & 111.1 & 303.1 & 18.8 & 86.1 \\
\hline \multirow[t]{4}{*}{ Shanghai } & 28 Mar 2006-30 Apr 2007 & 32 & 30 & 32 & 108 & 73.3 & 213.7 & 7.8 & 44.5 \\
\hline & 1 Aug 2006-26 Aug 2007 & 26 & 26 & 20 & 61.2 & 47.5 & 131.6 & 12.4 & 21.8 \\
\hline & 20 Mar 2007-21 Apr 2007 & 32 & 32 & 25.3 & 80.7 & 115.4 & 913.9 & 8.4 & 17.4 \\
\hline & 23 Jul 2007-19 Aug 2007 & 28 & 28 & 30.5 & 91 & 105.1 & 147.7 & 3.8 & 7.7 \\
\hline \multirow[t]{3}{*}{ MT } & 14 Mar 2006-6 May 2006 & 16 & 15 & 46.6 & 128.1 & 116.8 & 287.6 & 17.2 & 59.1 \\
\hline & 2 Jun 2006-30 Jun 2006 & 27 & 21 & 123.1 & 135.0 & 235.7 & 276.9 & 48 & 49.2 \\
\hline & 26 Mar 2007-18 May 2007 & 31 & 18 & 70.1 & 143.8 & 167.4 & 230.4 & 18 & 39.6 \\
\hline
\end{tabular}

Ion Chromatography (Model: Dionex 3000), which consists of a separation column (Dionex Ionpac AS11 for anion and CS12A for cation), a guard column (Dionex Ionpac AG 11 for anion and AG12A for cation), a self-regenerating suppressed conductivity detector (Dionex Ionpac ED50), and a gradient pump (Dionex Ionpac GP50). The gradient mobile phase generated by EG-3000 was used for anion detection, while the weak acid eluent (20 mM MSA) for cation detection. The recovery of each ion was in the range of 80-120\%. The relative standard deviation of each ion was less than $5 \%$ for reproducibility test. The limits of detection $(\mathrm{S} / \mathrm{N}=3)$ were less than $0.04 \mathrm{mg} \mathrm{L}^{-1}$ for anions and $0.006 \mathrm{mg} \mathrm{L}^{-1}$ for cations. The quality assurance was routinely carried out by using Standard Reference Materials (GBW 08606) produced by National Research Center for Certified Reference Materials, China. Blank values were subtracted from sample determinations. The details were given elsewhere (Yuan et al., 2003).

\subsubsection{Element analysis}

Half of each sample filter and blank filter was digested at $170{ }^{\circ} \mathrm{C}$ for $4 \mathrm{~h}$ in high-pressure Teflon digestion vessel with $3 \mathrm{~mL}$ concentrated $\mathrm{HNO}_{3}, 1 \mathrm{~mL}$ concentrated $\mathrm{HCl}$, and $1 \mathrm{~mL}$ concentrated HF. After cooling, the solutions were dried, and then added $0.1 \mathrm{~mL}$ concentrated $\mathrm{HNO}_{3}$, and diluted to $10 \mathrm{~mL}$ with deionized water (resistivity of $18 \mathrm{M} \Omega \mathrm{cm}^{-1}$ ). Total 19 elements (Al, Fe, Mn, Mg, Ti, Na, Sr, Ca, Co, Cr, Ni, Cu, $\mathrm{Pb}, \mathrm{Zn}, \mathrm{Cd}, \mathrm{V}, \mathrm{S}, \mathrm{As}$ and $\mathrm{P}$ ) were determined by Inductively Coupled Plasma Atomic Emission Spectroscopy (ICPAES, model: ULTIMA, made by JOBIN-YVON Company, France). All the reagents used were of the highest grade. All the preparation was carried out in a Class-100 clean bench. The recovery rates were measured with standard addition, and the recoveries of each element were in the range of $95 \%$ to $105 \%$. The relative standard deviations of each element were less than $2 \%$ for reproducibility test. The geochemistry reference matter (TBW07401) made by the Center for National Standard Matter was also analyzed simultaneously to check the reliability of analysis (Han et al., 2005). The detection limits (3s) for typical elements of $\mathrm{Al}, \mathrm{As}, \mathrm{Ca}$, $\mathrm{Cd}, \mathrm{Co}, \mathrm{Fe}, \mathrm{Pb}, \mathrm{Cu}$, and $\mathrm{Zn}$ were $1.5,5,0.03,0.35,0.6$, $0.5,5,0.6$, and $0.3 \mu \mathrm{g} \mathrm{L}^{-1}$, respectively. Black carbon (BC) was analyzed with Smokerstain Reflectometer (UK, Model, M43D). The detailed analytical procedures were given elsewhere (Zhuang et al., 2001).

\subsection{Meteorological data, fire spot map and trace gases}

The meteorological data, including temperature, relative humidity (RH), dew point, wind speed, wind direction, atmospheric pressure, visibility etc., were collected from http://www.wunderground; Data of $\mathrm{SO}_{2}, \mathrm{NO}_{2}$ in Shanghai and MT were collected from http://www.envir.gov.cn and http://www.tahb.gov.cn; Fire spot data were got from MODIS Global Fire Mapping Service (http://firefly.geog. umd.edu/firemap/); $\mathrm{O}_{3}$ and $\mathrm{CO}$ were detected with a commercial UV photometric analyzer (Thermo Environment Instruments Inc., Model 49) that had a detection limit of 2 ppbv and a 2-sigma (2-s) precision of $2 \mathrm{ppbv}$ for a 2- min average. CO was measured with a gas filter correlation, a nondispersive infrared analyzer (Advanced Pollution Instrumentation Inc., Model 300) with a heated catalytic scrubber for baseline determination, which was conducted every $2 \mathrm{~h}$. The detection limit was $30 \mathrm{ppbv}$ for a 2 -min average, with a 2-s precision of about $1 \%$ for a level of 500 ppbv (2-min average). The overall uncertainty was estimated to be $10 \%$. 
Table 2. Mass concentrations $\left(\mu \mathrm{g} \mathrm{m}^{-3}\right)$ and size distributions of aerosols at the summit of MT and other sampling sites.

\begin{tabular}{llrrr|rrr}
\hline \multirow{2}{*}{ Sites } & time & \multicolumn{3}{c|}{ Spring } & \multicolumn{3}{c}{ Summer } \\
\cline { 3 - 7 } & & $\mathrm{PM}_{2.5}$ & TSP & PM $_{2.5} / \mathrm{TSP}$ & $\mathrm{PM}_{2.5}$ & $\mathrm{TSP}$ & $\mathrm{PM}_{2.5} / \mathrm{TSP}$ \\
\hline \multirow{2}{*}{ Shanghai } & $2003-2005^{\mathrm{a}}$ & 135.0 & 293.0 & 0.46 & 72.0 & 167.0 & 0.43 \\
& 2006 & 32.0 & 108.0 & 0.30 & 20.0 & 61.2 & 0.33 \\
& 2007 & 25.3 & 80.7 & 0.31 & 30.5 & 91.0 & 0.34 \\
MT & 2006 & 46.6 & 128.1 & 0.37 & 123.1 & 135.0 & 0.91 \\
& 2007 & 70.1 & 143.8 & 0.49 & & & \\
Urumqi & 2007 & 81.9 & 232.5 & 0.35 & 45.9 & 172.6 & 0.27 \\
Beijing & $2002^{\mathrm{b}}$ & 212.6 & 1410.1 & 0.15 & 79.6 & 224.6 & 0.35 \\
& 2007 & 77.1 & 160.9 & 0.48 & 78.4 & 114.5 & 0.68 \\
Duolun & 2007 & 64.1 & 176.2 & 0.36 & & & \\
Tianchi & 2007 & 24.0 & 57.7 & 0.42 & & & \\
Yulin & 2007 & 83.0 & 354.4 & 0.23 & & & \\
\hline
\end{tabular}

a Wang et al. (2006b); ${ }^{\mathrm{b}}$ Wang et al. (2006a).

Table 3. Meteorological conditions and concentrations of gases $\left(\mathrm{O}_{3}, \mathrm{CO}\right.$, Peroxide $)$ in ambient air at MT.

\begin{tabular}{lrrrrrrrr}
\hline Month & $\begin{array}{r}\text { Temp. } \\
\left({ }^{\circ} \mathrm{C}\right)\end{array}$ & $\begin{array}{r}\text { Dew Temp. } \\
\left({ }^{\circ} \mathrm{C}\right)\end{array}$ & $\begin{array}{r}\text { Humidity } \\
(\%)\end{array}$ & $\begin{array}{r}\text { Visibility } \\
(\mathrm{km})\end{array}$ & $\begin{array}{r}\text { Windy Speed } \\
(\mathrm{mph})\end{array}$ & \multicolumn{2}{c}{$\begin{array}{r}\text { Concentrations } \\
(\mathrm{ppbv})\end{array}$} \\
\hline & & & & & & $\mathrm{O}_{3}$ & $\mathrm{CO}$ & Peroxide \\
March & 2 & -10 & 36 & 10 & 20 & 56 & 358 & 0.17 \\
April & 7 & 2 & 49 & 10 & 22 & 61 & 425 & \\
June & 17 & 10 & 60 & 9.0 & 16 & 71 & 516 & 0.55 \\
\hline
\end{tabular}

Measurement method of peroxide: A 26 -turn coil was used to strip the peroxides out of the air and into a liquid phase by water $\left(0.42 \mathrm{~mL}^{-1}\right)$, which was sucked through a 10-turn coil ( $\left.0.42 \mathrm{~mL} \mathrm{~min}^{-1}\right)$ at which buffer (potassium hydrogen phthalate (KHP, Fisher Scientific) and tetrasodium ethylenediaminetetraacetate (Na4EDTA, Fluka Scientific)) and fluorescence (POPHA (Fluka Scientific), horseradish peroxidase (Sigma Chemical Co.), KHP, and Na4EDTA) solutions were added, then the liquid entered a pH booster cell that contained $30 \%$ ammonium hydroxide (Sigma Chemical Co.) to adjust solution $\mathrm{pH}$ from 6 to approximately 10 . After going through a debubbler $\left(0.42 \mathrm{~mL}\right.$ min ${ }^{-1}$ ), where the bubbles were removed, the fluorescence of the dimmer was detected using a fluorimeter (Spectrovision FD-100, Groton Technology Inc., Concord, MA) with excitation and emission wavelength of $326 \mathrm{~nm}$ and $400 \mathrm{~nm}$, respectively.

\section{Results and discussion}

\subsection{Overview of particle matters at summit of MT}

\subsubsection{Mass concentrations of PM and size distribution}

Temporal variations of mass concentrations and the corresponding deviations of $\mathrm{PM}_{2.5}$ and TSP at MT and other sampling sites are summarized in Fig. 2 and Tables 1-2. TSP were relatively seasonal stable $\left(128.1 \mu \mathrm{g} \mathrm{m}^{-3} / 143.8 \mu \mathrm{g} \mathrm{m}^{-3}\right.$ in spring 2006/2007 and $135.0 \mu \mathrm{g} \mathrm{m}^{-3}$ in summer 2006), while $\mathrm{PM}_{2.5}$ had highly seasonal variation with much higher concentration in summer $2006\left(123.1 \mathrm{\mu g} \mathrm{m}^{-3}\right)$ than in spring 2006/2007 (46.6 $\left.\mu \mathrm{g} \mathrm{m}^{-3} / 70.1 \mu \mathrm{g} \mathrm{m}^{-3}\right)$ at MT. $\mathrm{PM}_{2.5}$ was relatively higher in spring 2007 (26 March-18 May) compared to that in spring 2006 (14 March-6 May), which was likely attributed to the different sampling periods and it will be interpreted in Sect. 3.2.1. TSP from MT was comparable with those from other sampling sites in ground level, and there was no obvious decrease at a height of $1534 \mathrm{~m}$ compared to those at ground level, as expected. Both TSP and $\mathrm{PM}_{2.5}$ at MT were much higher than those at Tianchi that is also located at a high land $(1900 \mathrm{~m})$. Aerosol pollutions at MT were as severe as or even worse than those at ground level, e.g. $\mathrm{PM}_{2.5}$ at MT were much higher than those at other sites, including the sites in megacities, Beijing and Shanghai, at ground level in summer. The average ratio of $\mathrm{PM}_{2.5} / \mathrm{TSP}$ was 0.37 in spring and 0.91 in summer in 2006, indicating that fine particles dominated in summer while coarse particles in spring. The seasonal variation of fine particles should be firstly attributed to the seasonally different meteorology at MT (Table 3), which showed typical seasonal variations with higher temperature, lower windy speed, lower atmospheric pressure and more solar radiation in summer than those in spring. The meteorology at MT could strengthen the vertical convection of the air, and the regional anthropogenic pollutants on the ground surface could easily transport upward, resulting in the increase of the height of PBL, that 


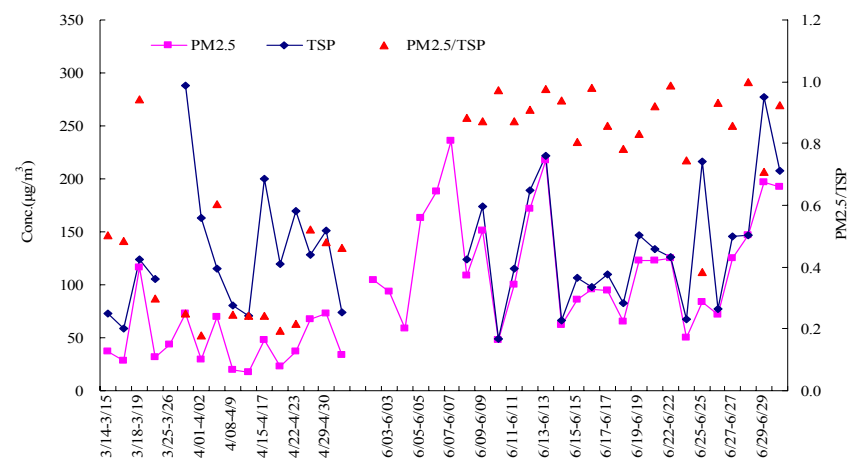

Fig. 2. Daily variations of TSP and $\mathrm{PM}_{2.5}$ from 14 March to 30 June in 2006 at MT.

was even higher than the summit of MT. On the contrary, the height of the PBL in spring was so compressed that it used to be below the summit of MT, and the Mountain-valley breezes could not fully develop due to the weak solar radiation and the strong regional winds in ground level. Hence, the transport upward of the regional pollutants to the summit was less frequent in spring than in summer, which resulted in lower concentrations of fine particles in spring. Besides, dust storms mostly occur in spring and MT is located on the very pathway of its long-range transport from central Asia to the northern America (Arimoto et al., 1996; Zhang et al., 1997; Sun et al., 2010). Thus, in those days with high wind speed in spring, higher ratio of those coarse particles to the total aerosol mass was often observed even at elevation of more than $1500 \mathrm{~m}$.

\subsubsection{Ionic and elemental composition of the particles at MT}

Mass concentrations of ions in $\mathrm{PM}_{2.5}$ and TSP at MT are listed in Table 4. Water soluble ions contributed $10.82 \%$ of TSP and $23.99 \%$ of $\mathrm{PM}_{2.5}$ in mass in spring, while $40.89 \%$ and $41.08 \%$ in summer. This result revealed evidently that the secondary aerosol possessed much larger part in summer than in spring. The ratios of total ions to the total mass in $\mathrm{PM}_{2.5}$ were higher than those in TSP both in summer and spring, suggesting that the pollution components, such as $\mathrm{SO}_{4}^{2-}, \mathrm{NH}_{4}^{+}, \mathrm{NO}_{3}^{-}$, existed more in fine mode. These three major water soluble ions accounted for $61.50 \%$ in spring and $72.65 \%$ in summer of the total ions measured in $\mathrm{PM}_{2.5}$, while $69.20 \%$ and $71.47 \%$ in TSP, respectively (Table 5). Also, higher concentration of $\mathrm{K}^{+}$, the tracer of the biomass source, in summer was observed, which could account for $8.26 \%$ of total ions in TSP. Whereas, higher concentration of $\mathrm{Ca}^{2+}$, likely more from the Asian dust source, in spring, accounted for $21.93 \%$ of the total ions in TSP.

Water-soluble ions are proved to play key roles in many atmospheric processes, such as cloud formation, visibility degradation, solar radiation, acidification of cloud, rain, and
Table 4. Water-soluble ions in $\mathrm{PM}_{2.5}$ and TSP and the corresponding ratios of summer/spring at $\mathrm{MT}$.

\begin{tabular}{|c|c|c|c|c|c|c|}
\hline & \multicolumn{4}{|c|}{ Concentration $\left(\mu \mathrm{g} \mathrm{m}^{-3}\right)$} & \multirow{2}{*}{\multicolumn{2}{|c|}{$\begin{array}{c}\text { Ratio } \\
\text { (Summer/Spring) }\end{array}$}} \\
\hline & \multicolumn{2}{|c|}{ Spring } & \multicolumn{2}{|c|}{ Summer } & & \\
\hline & TSP & $\mathrm{PM}_{2.5}$ & TSP & $\mathrm{PM}_{2.5}$ & TSP & $\mathrm{PM}_{2.5}$ \\
\hline $\mathrm{NH}_{4}^{+}$ & 1.48 & 0.88 & 10.40 & 9.56 & 7.03 & 10.86 \\
\hline $\mathrm{Na}^{+}$ & 0.68 & 0.56 & 1.36 & 1.28 & 2.00 & 2.29 \\
\hline $\mathrm{K}^{+}$ & 0.72 & 0.48 & 4.56 & 4.41 & 6.33 & 9.19 \\
\hline $\mathrm{Mg}^{2+}$ & 0.24 & 0.16 & 0.24 & 0.16 & 1.00 & 1.00 \\
\hline $\mathrm{Ca}^{2+}$ & 3.04 & 1.72 & 2.88 & 1.76 & 0.95 & 1.02 \\
\hline $\mathrm{F}^{-}$ & 0.13 & 0.11 & 0.02 & 0.03 & 0.15 & 0.27 \\
\hline $\mathrm{Cl}^{-}$ & 0.83 & 0.65 & 2.18 & 2.30 & 2.63 & 3.54 \\
\hline MSA & 0.02 & 0.01 & 0.22 & 0.54 & 11.00 & 54.00 \\
\hline $\mathrm{HCOO}^{-}$ & 0.12 & 0.06 & 0.12 & 0.16 & 1.00 & 2.67 \\
\hline $\mathrm{CH}_{3} \mathrm{COO}^{-}$ & 0.27 & 0.23 & 1.83 & 1.32 & 6.78 & 5.74 \\
\hline $\mathrm{C}_{2} \mathrm{O}_{4}^{2-}$ & 0.15 & 0.10 & 0.37 & 0.48 & 2.47 & 4.80 \\
\hline $\mathrm{CH}_{2} \mathrm{C}_{2} \mathrm{O}_{4}^{2-}$ & 0.42 & 0.22 & 0.65 & 0.49 & 1.55 & 2.23 \\
\hline $\mathrm{C}_{2} \mathrm{H}_{4} \mathrm{C}_{2} \mathrm{O}_{4}^{2-}$ & 0.02 & 0.01 & 0.04 & 0.10 & 2.00 & 10.00 \\
\hline $\mathrm{NO}_{3}^{-}$ & 3.61 & 3.24 & 8.82 & 8.21 & 2.44 & 2.53 \\
\hline $\mathrm{SO}_{4}^{2-}$ & 4.47 & 2.72 & 20.73 & 20.26 & 4.64 & 7.45 \\
\hline $\mathrm{NO}_{2}^{-}$ & 0.03 & 0.03 & 0.12 & 0.14 & 4.00 & 4.67 \\
\hline $\mathrm{PO}_{4}^{3-}$ & 0.01 & n.a & 0.01 & 0.02 & 1.00 & \\
\hline Total ions $\left(\mathrm{C}_{\mathrm{IC}}\right)$ & 13.86 & 11.18 & 54.47 & 51.53 & 3.93 & 4.61 \\
\hline Total mass $\left(C_{P}\right)$ & 128.1 & 46.6 & 135 & 123.1 & 1.05 & 2.64 \\
\hline $\mathrm{C}_{\mathrm{IC}} / \mathrm{C}_{\mathrm{P}}(\%)$ & 10.82 & 23.99 & 40.35 & 41.86 & 3.73 & 1.74 \\
\hline $\mathrm{Ca}^{2+} /$ Total ions & 21.93 & 15.38 & 5.29 & 3.42 & & \\
\hline $\mathrm{K}^{+} /$Total ions & 5.19 & 4.29 & 8.37 & 8.56 & & \\
\hline
\end{tabular}

$\mathrm{C}_{\mathrm{IC}}$ : Total mass concentrations of water- soluble ions $\left(\mu \mathrm{g} \mathrm{m}^{-3}\right)$. $\mathrm{C}_{\mathrm{P}}$ : Mass concentrations of TSP or $\mathrm{PM}_{2.5}\left(\mu \mathrm{g} \mathrm{m}^{-3}\right)$.

fog, and haze formation because of their affinity with water (Tsai et al., 1999; Novakov et al., 1993; Matsumoto et al., 1997; Facchini et al., 2000). Haze mostly occurred in stable, warm, and moist air, and was characterized by the high level of fine particles with high percentage of certain water soluble ions, such as $\mathrm{SO}_{4}^{2-}, \mathrm{NH}_{4}^{+}$, and $\mathrm{NO}_{3}^{-}$, in the aerosols. Certain characteristics of the aerosols collected at MT in summer and spring and at Beijing in dust, haze, and clear days are summarized in Table 5. $\mathrm{C}_{\mathrm{IC}} / \mathrm{C}_{\mathrm{P}}, \mathrm{C}_{(\mathrm{S}+\mathrm{N}+\mathrm{A})} / \mathrm{C}_{\mathrm{IC}}$, SOR and NOR at $\mathrm{MT}$ in summer were very similar to those in haze days in Beijing, suggesting that haze could occur frequently in summer at the summit of MT, which could be proved by the lower visibility $(9.0 \mathrm{~km})$ on average at MT.

The concentrations of nineteen elements and black carbon (BC) in aerosols at MT are listed in Table 6, which showed clearly that crustal element ( $\mathrm{Ca}, \mathrm{Ma}, \mathrm{Al}, \mathrm{Mn}, \mathrm{Ti}, \mathrm{Sr}$, and $\mathrm{Na}$ ) were higher in spring, while pollution elements $(\mathrm{Pb}, \mathrm{Cr}, \mathrm{Cd}$, $\mathrm{Zn}, \mathrm{Ni}, \mathrm{S}, \mathrm{BC}$ ), except $\mathrm{As}$ and $\mathrm{Cu}$, were higher in summer. The elements could be classified into four groups according to their enrichment factors $\left(\mathrm{EFs}=(\mathrm{X} / \mathrm{Al})_{\text {aerosol }} /(\mathrm{X} / \mathrm{Al})_{\text {crust }}\right)$ : high enriched pollution elements ( $\mathrm{Pb}$ and $\mathrm{As})$, medium enriched ( $\mathrm{S}$ and $\mathrm{Zn}$ ), slightly enriched ( $\mathrm{Ni}, \mathrm{Cu}$ and $\mathrm{Cr}$ ), and non-enriched crustal metals ( $\mathrm{Ca}, \mathrm{Ma}, \mathrm{Al}, \mathrm{Mn}, \mathrm{Ti}, \mathrm{Sr}$ and $\mathrm{Na}$ ). EFs of all crustal elements (see Fig. 3) were higher in TSP 
Table 5. SOR, NOR of ambient air and main water-soluble ions in $\mathrm{PM}_{2.5}$ and TSP at MT and Beijing.

\begin{tabular}{llrr|rrr}
\hline & \multicolumn{3}{c|}{ MT } & \multicolumn{3}{c}{ Beijing* } \\
\cline { 2 - 7 } & & Spring & Summer & Haze days & Dust days & Clear days \\
\hline $\mathrm{PM}_{2.5} / \mathrm{TSP}$ & 0.37 & 0.91 & 0.39 & 0.21 & 0.31 & \\
$\mathrm{C}_{\mathrm{IC}} / \mathrm{C}_{\mathrm{P}}(\%)$ & $\mathrm{PM}_{2.5}$ & 23.99 & 41.08 & 53.20 & 9.30 & 15.20 \\
& $\mathrm{TSP}$ & 10.82 & 40.89 & 33.30 & 3.30 & 32.2 \\
$\mathrm{C}_{(\mathrm{S}+\mathrm{N}+\mathrm{A})} / \mathrm{C}_{\mathrm{IC}}(\%)$ & $\mathrm{PM}_{2.5}$ & 61.50 & 72.65 & 87.10 & 63.70 & 73.00 \\
& $\mathrm{TSP}_{\mathrm{SOR}}$ & 69.20 & 71.47 & 79.90 & 45.70 & 66.10 \\
& $\mathrm{PM}_{2.5}$ & 0.08 & 0.31 & 0.27 & 0.29 & 0.15 \\
$\mathrm{NOR}$ & $\mathrm{TSP}$ & 0.09 & 0.32 & 0.24 & 0.25 & 0.17 \\
& $\mathrm{PM}_{2.5}$ & 0.09 & 0.22 & 0.22 & 0.09 & 0.13 \\
& $\mathrm{TSP}$ & 0.10 & 0.26 & 0.29 & 0.16 & 0.18 \\
\hline
\end{tabular}

$\mathrm{C}_{(\mathrm{S}+\mathrm{N}+\mathrm{A})}$ : The sum of the concentrations of $\mathrm{SO}_{4}^{2-}, \mathrm{NO}_{3}^{-}$, and $\mathrm{NH}_{4}^{+}\left(\mu \mathrm{g} \mathrm{m}^{-3}\right)$.

$\mathrm{C}_{\mathrm{IC}}$ : Total mass concentrations of water- soluble ions $\left(\mu \mathrm{g} \mathrm{m}^{-3}\right)$.

$\mathrm{C}_{\mathrm{P}}$ : Mass concentrations of TSP or $\mathrm{PM}_{2.5}\left(\mu \mathrm{g} \mathrm{m}^{-3}\right)$.

SOR: Sulfur oxidation ratio, $\mathrm{SOR}=n \mathrm{SO}_{4}^{2-} /\left(n \mathrm{SO}_{4}^{2-}+n \mathrm{SO}_{2}\right)$.

NOR: Nitrogen oxidation ratio, $\mathrm{NOR}=n \mathrm{NO}_{3}^{-} /\left(n \mathrm{NO}_{3}^{-}+n \mathrm{NO}_{2}\right)$ ( $n$ refers to the molar concentration).

* Wang et al. (2006a).

Table 6. Concentrations $\left(\mu \mathrm{g} \mathrm{m}^{-3}\right)$ of elements in $\mathrm{PM}_{2.5}$ and TSP and the corresponding ratios of summer/spring at MT.

\begin{tabular}{lrrr|lrr}
\hline \multirow{2}{*}{ Elements } & \multicolumn{2}{c|}{ Concentration $\left(\mu \mathrm{g} \mathrm{m}^{-3}\right.$ or ng m $\left.^{-3}\right)$} & \multicolumn{2}{c}{ Ratio } \\
\cline { 2 - 7 } & \multicolumn{2}{c}{ Spring } & \multicolumn{2}{c|}{ Summer } & \multicolumn{2}{|c}{ Summer/Spring $)$} \\
& TSP & $\mathrm{PM}_{2.5}$ & \multicolumn{1}{c}{ TSP } & PM $_{2.5}$ & TSP & PM $_{2.5}$ \\
\hline $\mathrm{Al}$ & 3.01 & 1.20 & 2.20 & 1.96 & 0.73 & 1.63 \\
$\mathrm{Ca}$ & 3.95 & 1.75 & 2.61 & 1.72 & 0.66 & 0.98 \\
$\mathrm{Fe}$ & 2.18 & 0.81 & 1.69 & 0.71 & 0.77 & 0.88 \\
$\mathrm{Mg}$ & 1.02 & 0.35 & 0.50 & 0.42 & 0.50 & 1.19 \\
$\mathrm{Na}$ & 0.99 & 0.59 & 1.48 & 1.27 & 1.49 & 2.15 \\
$\mathrm{Zn}$ & 0.49 & 0.40 & 0.78 & 0.45 & 1.59 & 1.11 \\
$\mathrm{~S}$ & 1.49 & 0.90 & 6.96 & 6.73 & 4.52 & 7.48 \\
$\mathrm{BC}$ & 1.49 & 0.42 & 2.36 & 2.06 & 1.58 & 4.90 \\
$\mathrm{Ti}$ & 240.00 & 81.40 & 150.00 & 85.30 & 0.62 & 1.05 \\
$\mathrm{Sr}$ & 22.60 & 8.71 & 16.60 & 15.90 & 0.60 & 1.83 \\
$\mathrm{Mn}$ & 75.30 & 39.10 & 72.40 & 71.90 & 0.96 & 1.84 \\
$\mathrm{Cu}$ & 57.00 & 24.00 & 26.20 & 21.80 & 0.46 & 0.91 \\
$\mathrm{As}$ & 5.71 & 2.30 & 4.07 & 3.58 & 0.71 & 1.56 \\
$\mathrm{Cd}$ & 1.29 & 1.00 & 3.60 & 3.35 & 2.79 & 3.35 \\
$\mathrm{Co}$ & 1.79 & 1.01 & 3.48 & 2.78 & 1.94 & 2.75 \\
$\mathrm{Cr}$ & 23.00 & 22.90 & 98.50 & 85.40 & 4.28 & 3.73 \\
$\mathrm{Ni}$ & 7.49 & 7.41 & 22.70 & 19.80 & 3.03 & 2.67 \\
$\mathrm{~Pb}$ & 42.20 & 15.20 & 76.50 & 72.00 & 1.81 & 4.74 \\
$\mathrm{P}$ & 94.60 & 36.60 & 130.00 & 84.60 & 1.37 & 2.31 \\
$\mathrm{~V}$ & 5.35 & $\mathrm{BDL}$ & $\mathrm{BDL}$ & $\mathrm{BDL}$ & & \\
\hline
\end{tabular}

BDL:Below detection limits; BC: Black carbon; ${ }^{*}$ Unit after BC: $\mathrm{ng} \mathrm{m}^{-3}$.

and lower in $\mathrm{PM}_{2.5}$, while pollution elements were higher in $\mathrm{PM}_{2.5}$ and lower in TSP. EFs of As and Pb exhibited different seasonal variations with higher $\mathrm{EF}$ of $\mathrm{Pb}$ in summer and higher EF of As in spring.

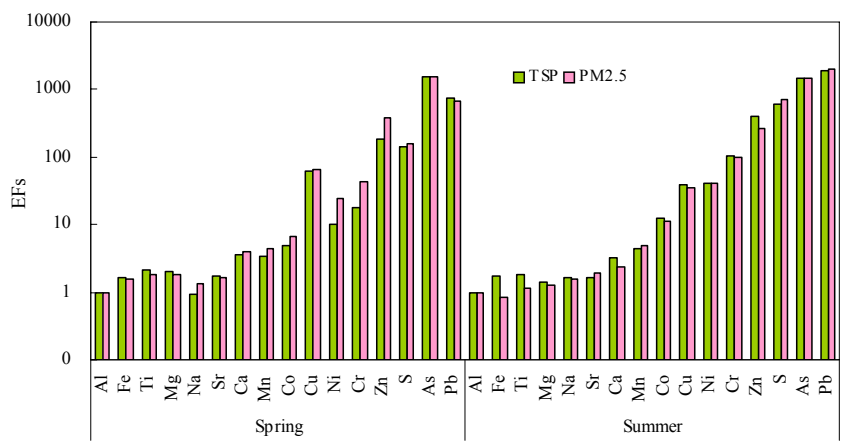

Fig. 3. Enrichment factors (EFs) of elements at MT in spring and summer, 2006.

\subsubsection{Acidity of the aerosols at MT}

Figure 4 shows the variations of $\mathrm{pH}$ of the filtrates of aerosols at MT, and it indicated that $\mathrm{pH}$ decreased obviously from spring to summer. The mean $\mathrm{pH}$ values of the aqueous filtrates of aerosols collected at MT and other sampling sites are compared in Table 7. The aerosols at MT showed higher acidity for both $\mathrm{PM}_{2.5}(\mathrm{pH}=4.62)$ and TSP $(\mathrm{pH}=4.92)$ in summer in comparison with the weak acidity of $\mathrm{PM}_{2.5}$ $(\mathrm{pH}=5.92)$ and slight alkalinity $(\mathrm{pH}=7.22)$ of TSP in spring. The $\mathrm{pH}$ of aerosols at MT in summer was the lowest, while TSP in spring showed slight alkalinity, which was similar to those from Tazhong $(\mathrm{pH}=7.39$, original source of dust storm) and from Beijing in supper dust day $(\mathrm{pH}=7.25$, Wang et al., 2005). The higher acidity of aerosols at MT in summer was further supported by the fact that the $\mathrm{pH}$ of rain samples in summer at MT was obviously lower than those in other seasons (Wang et al., 2006c). The measured acidity of 
Table 7. $\mathrm{pH}$ of aqueous filtrates of $\mathrm{PM}_{2.5}$ and TSP aerosols at different sampling sites.

\begin{tabular}{lccccc}
\hline \multirow{2}{*}{ Sites } & \multicolumn{2}{c}{ Spring } & \multicolumn{2}{c}{ Summer } & Reference \\
& $\mathrm{PM}_{2.5}$ & TSP & $\mathrm{PM}_{2.5}$ & TSP & \\
\hline MT & 5.92 & 7.22 & 4.62 & 4.92 & This study \\
Shanghai & 5.27 & 6.48 & 5.29 & 6.37 & This study \\
Urumqi & 5.49 & 6.21 & & & This study \\
Tianchi & 5.81 & 6.35 & & & This study \\
Tazhong & 6.61 & 7.39 & & & This study \\
Beijing (Normal days) & 6.54 & 6.79 & 5.92 & 6.26 & Wang et al. (2005) \\
Beijing (Supper dust days) & 7.25 & 7.54 & & & Wang et al. (2005) \\
Beijing (Haze days) & 5.33 & 6.27 & & & Wang et al. (2006a) \\
\hline
\end{tabular}

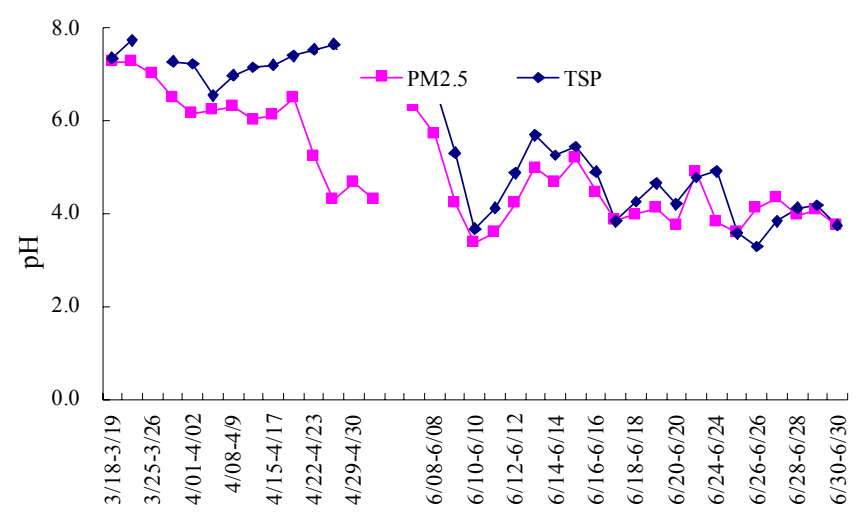

Fig. 4. Daily variations of $\mathrm{pH}$ of aqueous filtrates of aerosols at MT, 2006.

aerosols is determined by the presence and the proportions of the cations and anions in the filtrates of aerosols. In addition, the ratio of equivalent concentrations of total cations to total anions (C/A) should be equal to 1, if all the cations and anions in the aerosol were measured. However, $\mathrm{CO}_{3}^{2-}$ and $\mathrm{HCO}_{3}^{-}$were not measured in this study due to the limitation of ion chromatography, hence, the difference of the total anions and cations could be used to roughly estimate the amount of $\mathrm{CO}_{3}^{2-}$ and $\mathrm{HCO}_{3}^{-}$unmeasured (Wang et al., 2005). $\mathrm{C} / \mathrm{A}$ of aerosols in spring at MT reached 1.6 , while only 1.1 in summer, suggesting that much more carbonate or bicarbonate presented in the aerosols at MT in spring. The remarkable increase of $\mathrm{SO}_{4}^{2-}, \mathrm{NO}_{3}^{-}$and organic acids in summer shown in Table 4 indicated that in summer much more aerosols at MT was from secondary pollution, which would lead to the lower $\mathrm{pH}$ of the filtrates. Compared to the $\mathrm{pH}$ of those aerosols collected from Shanghai in summer (5.29 in $\mathrm{PM}_{2.5}$ and 6.37 in TSP), the aerosols at MT showed even higher acidity, suggesting that the secondary air pollution at MT in summer was even severer than that in Shanghai.

\subsection{Sources and formation mechanisms of aerosols at summit of MT}

\subsubsection{Influence of biomass burning}

Biomass burning includes those from grassland, forest, and crop residue, among which more than $60 \%$ are from crop residue burning in the world (Streets et al., 2003). With the rapid development of economy in China, crop residue is increasingly being burned openly in the field. In harvest every year $\sim 5.182 \times 10^{7}$ ton crop residues (accounted for $40.0 \%$ of the total crop residues in China) were directly burnt openly, especially in central eastern China, including Shandong, Jiangsu, Henan, Hebei provinces. Shandong, where MT is located, was in number 1 among those provinces mentioned above with the largest amount of crop residues $\left(1.798 \times 10^{7} \mathrm{t}\right)$ to be burned openly (Cao et al., 2007). Biomass burning emissions are known to contribute a considerable amount of PM and gaseous pollutants to the air, and crop residues contribute more fine particles and gaseous than other biomaterial residues (Cao et al., 2005; Zhu et al., 2005).

Water soluble potassium is a good tracer for aerosols formed from biomass burning (Andreae, 1983). Sources of total potassium ion $\left(\mathrm{K}_{\mathrm{Total}}^{+}\right)$in aerosols might be attributed to soot from biomass burning, sea salt, and crustal dust. Elemental $\mathrm{Al}$ and $\mathrm{Na}^{+}$could be the good markers of crustal dust and sea salt respectively, as the composition of $\mathrm{Na}$, $\mathrm{K}$, and $\mathrm{Al}$ in sea water and in crustal dust were found to be: $\mathrm{Na}: 31 \%, \mathrm{~K}: 1.1 \%$, Al:0\%, and $\mathrm{Na}: 2.6 \%, \mathrm{~K}: 2.9 \%$, $\mathrm{Al}: 7.7 \%$, respectively (Wedepohl, 1995), which showed that the percentage of $\mathrm{K}^{+}$were much lower than $\mathrm{Na}^{+}$in sea salt and also lower than $\mathrm{Al}$ in crustal dust. This means that the concentrations of $\mathrm{Na}^{+}$and $\mathrm{Al}$ in the aerosols would increase more than $\mathrm{K}^{+}$if the aerosols were from sea salt and crustal dust. Figure 5 showed that $\mathrm{K}^{+}$on certain days in summer was significant higher than $\mathrm{Na}^{+}$and $\mathrm{Al}$ with remarkable increase from the normal days, which suggested that the high concentrations of $\mathrm{PM}_{2.5}$ in summer could likely from biomass burning rather than sea water or crustal dust. It 
was reasonably assumed that the total potassium $\left(\mathrm{K}_{\mathrm{Total}}^{+}\right)$is the sum of dust-derived potassium $\left(\mathrm{K}_{\text {Crust }}^{+}\right)$, sea-salt-derived potassium $\left(\mathrm{K}_{\mathrm{SS}}^{+}\right)$, and biomass burning-derived potassium $\left(\mathrm{K}_{\mathrm{BB}}^{+}\right)$i.e. $\mathrm{K}_{\mathrm{Total}}^{+}=\mathrm{K}_{\text {Crust }}^{+}+\mathrm{K}_{\mathrm{SS}}^{+}+\mathrm{K}_{\mathrm{BB}}^{+}$(Virkkula et al., 2006), we can calculate the biomass burning potassium $\left(\mathrm{K}_{\mathrm{BB}}^{+}\right)$as $\mathrm{K}_{\mathrm{BB}=}^{+} \mathrm{K}_{\text {Total }}^{+}-\mathrm{K}_{\text {Crust }}^{+}-\mathrm{K}_{\mathrm{SS}}^{+}$. Assuming $\mathrm{Na}^{+}$in aerosol is from crust and sea salt only, i.e. $\mathrm{Na}_{\text {Total }}^{+}=\mathrm{Na}_{\text {Crust }}^{+}+\mathrm{Na}_{\mathrm{SS}}^{+}$, where $\mathrm{Na}_{\text {Total }}^{+}$is the concentration of $\mathrm{Na}^{+}$in the aerosol sample, and $\mathrm{Al}$ in aerosol is originated from crust only, thus, $\mathrm{K}_{\text {Crust }}^{+}$ and $\mathrm{K}_{\mathrm{SS}}^{+}$can be estimated through the ratios of $\mathrm{K}^{+} / \mathrm{Al}$ and $\mathrm{Na}^{+} / \mathrm{Al}$ in the aerosol sample and the ratio of $\mathrm{K}^{+} / \mathrm{Na}^{+}$in sea salt, i.e. $\mathrm{K}_{\text {Crust }}^{+}=\left(\mathrm{K}^{+} / \mathrm{Al}\right)_{\text {crust }} \times \mathrm{Al}_{\text {crust }}$ and $\mathrm{K}_{\mathrm{SS}}^{+}=\left(\mathrm{Na}_{\text {Total }}^{+}\right.$ $\left.\left(\mathrm{Na}^{+} / \mathrm{Al}\right)_{\text {crustl }} \times \mathrm{Al}_{\text {crustl }}\right) \times\left(\mathrm{K}^{+} / \mathrm{Na}^{+}\right)_{\text {sea-salt. }}$ The ratio of $\mathrm{K}^{+} / \mathrm{Na}^{+}$in those particles from sea salt is constant $(0.037)$ (Chester, 1990), whereas the ratios of $\mathrm{K}^{+} / \mathrm{Al}$ and $\mathrm{Na}^{+} / \mathrm{Al}$ in crustal dust were different between the samples collected from different sites because of the different background and the different influence of the human activities on each site. We now have two methods to estimate the biomass burning derived potassium $\left(\mathrm{K}_{\mathrm{BB}}^{+}\right)$: (1) Using the minimum ratios of $\mathrm{K}^{+} / \mathrm{Al}$ of 0.152 and $\mathrm{Na}^{+} / \mathrm{Al}$ of 0.240 in the $\mathrm{PM}_{2.5}$ aerosol sample collected at MT on 26 April 006 among all samples collected to calculate the background value of $\mathrm{K}^{+}$and $\mathrm{Na}^{+}$in crustal dust, then the biomass burning derived potassium $\left(\mathrm{K}_{\mathrm{BB}}^{+}\right)$is given from $\mathrm{K}_{\mathrm{BB}=}^{+} \mathrm{K}_{\mathrm{Total}}^{+}$ $\mathrm{K}_{\text {Crust }}^{+}-\mathrm{K}_{\mathrm{SS}}^{+}$, where $\mathrm{K}_{\text {Crust }}^{+}=\left(\mathrm{K}^{+} / \mathrm{Al}\right)_{\text {Aerosol }} \times \mathrm{Al}_{\text {Aerosol }}$, $\mathrm{Al}_{\text {Aerosol }}$ is the $\mathrm{Al}$ concentration measured in $\mathrm{PM}_{2.5}$, i.e. $\quad \mathrm{K}_{\text {Crust }}^{+}=0.152 \times \mathrm{Al}_{\text {Aerosol }}, \quad$ and $\mathrm{K}_{\mathrm{SS}}^{+}=\left(\mathrm{Na}_{\text {Total }}^{+}\right.$ $\left.\left(\mathrm{Na}^{+} / \mathrm{Al}\right)_{\text {Aerosol }} \times \mathrm{Al}_{\text {Aerosol }}\right) \times\left(\mathrm{K}^{+} / \mathrm{Na}^{+}\right)_{\text {sea-salt }}$,

i.e. $\quad \mathrm{K}_{\mathrm{SS}}^{+}=\left(\mathrm{Na}_{\text {Total }}^{+}-0.240 \times \mathrm{Al}_{\text {Aerosol }}\right) \times 0.037$, (2) Using the ratios of $\mathrm{K}^{+} / \mathrm{Al}$ of 0.107 and $\mathrm{Na}^{+} / \mathrm{Al}$ of 0.031 measured in the soil samples collected at MT to calculate the background value of $\mathrm{K}^{+}$and $\mathrm{Na}^{+}$in crustal dust, then the biomass burning derived potassium $\left(\mathrm{K}_{\mathrm{BB}}^{+}\right)$is given from

$\mathrm{K}_{\mathrm{BB}=}^{+} \mathrm{K}_{\text {Total }}^{+}-\mathrm{K}_{\text {Crust }}^{+}-\mathrm{K}_{\mathrm{SS}}^{+}$, where $\mathrm{K}_{\text {Crust }}^{+}$

$=\left(\mathrm{K}^{+} / \mathrm{Al}\right)_{\text {soil }} \times \mathrm{Al}_{\text {Aerosol }}$, i.e. $\mathrm{K}_{\text {Crust }}^{+}=0.107 \times \mathrm{Al}_{\text {Aerosol }}$, and

$\mathrm{K}_{\mathrm{SS}}^{+}=\left(\mathrm{Na}_{\text {Total }}^{+}-\left(\mathrm{Na}^{+} / \mathrm{Al}\right)_{\text {soil }} \times \mathrm{Al}_{\text {Aerosol }}\right) \times\left(\mathrm{K}^{+} / \mathrm{Na}^{+}\right)_{\text {sea-salt }}$,

i.e. $\mathrm{K}_{\mathrm{SS}}^{+}=\left(\mathrm{Na}_{\text {Total }}^{+}-0.031 \times \mathrm{Al}_{\text {Aerosol }}\right) \times 0.037$,

The concentrations of $\mathrm{K}_{\mathrm{BB}}^{+}$(biomass burning-derived $\mathrm{K}^{+}$) calculated with two methods mentioned above in $\mathrm{PM}_{2.5}$ collected at MT in 2006 are shown in Fig. 6. It can be seen clearly that very similar concentrations of $\mathrm{K}_{\mathrm{BB}}^{+}$were acquired by the two methods. The averaged $\mathrm{K}_{\mathrm{BB}}^{+}$were 0.40 and $4.30 \mu \mathrm{g} \mathrm{m}^{-3}$ in spring and summer, respectively, with the method of using the minimum ratios of $\mathrm{K}^{+} / \mathrm{Al}$ and $\mathrm{Na}^{+} / \mathrm{Al}$ in the aerosol sample to calculate the background value of $\mathrm{K}^{+}$and $\mathrm{Na}^{+}$in crustal dust, while the $\mathrm{K}_{\mathrm{BB}}^{+}$were 0.32 and $4.30 \mu \mathrm{g} \mathrm{m}^{-3}$ with the method of using the ratios of $\mathrm{K}^{+} / \mathrm{Al}$ and $\mathrm{Na}^{+} / \mathrm{Al}$ in the soil samples. The high level of $\mathrm{K}_{\mathrm{BB}}^{+}$

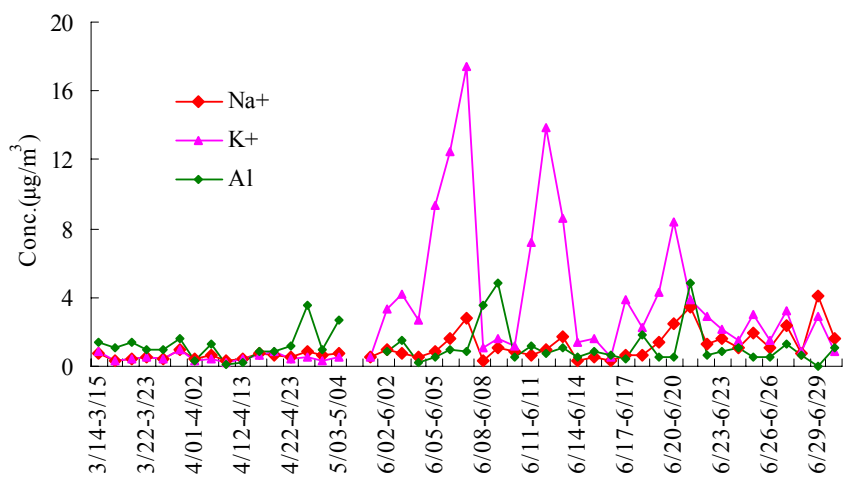

Fig. 5. Daily variations of $\mathrm{K}^{+}, \mathrm{Na}^{+}$, and $\mathrm{Al}$ in $\mathrm{PM}_{2.5}$ from 14 March to 30 June in 2006 at MT.

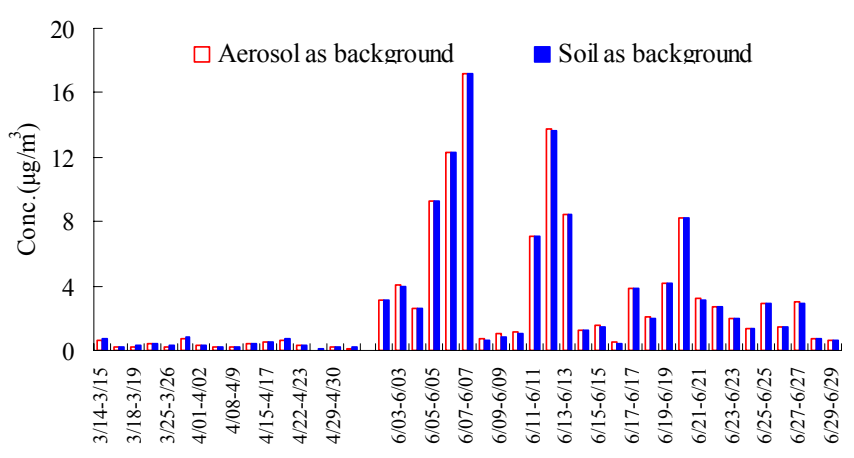

Fig. 6. Concentrations of biomass burning derived $\mathrm{K}^{+}$calculated with two methods in $\mathrm{PM}_{2.5}$ in 2006 at MT.

$\left(4.30 \mu \mathrm{g} \mathrm{m}^{-3}\right)$ in summer indicated that there were the significant part of the aerosols from biomass burning emissions at MT during the summer time. This result could also be confirmed by the fire spot data in this region, as shown in Fig. 7a-f. The amount of those fire spots distributed in the region surrounding MT increases obviously in May (Fig. 7c), and highly active fire disturbance appeared in June (Fig. 7d). The fire spots spread mainly to the south to MT during 19 June (Fig. 7e), and then extended to the northern places to MT during 10-19 June (Fig. 7f), which was in accordance to the harvest time of wheat/rice from south to north in this region.

The contributions of biomass burning, crustal dust, and other sources to the fine particles, $\mathrm{PM}_{2.5}$, in spring and summer 2006 at MT are shown in Fig. 8. To assess quantitatively the contributions of biomass burning openly from the agriculture residues to the formation of $\mathrm{PM}_{2.5}$ at MT, we used the ratio of $\mathrm{K}^{+} / \mathrm{PM}_{2.5}$ of $9.56 \%$ (wt \%) from the agriculture residues, i.e. biomass burning-derived $\mathrm{PM}_{2.5}=\mathrm{K}_{\mathrm{BB}}^{+} / 0.0956$, to calculate the mass of $\mathrm{PM}_{2.5}$ derived from biomass burning, for both $\mathrm{Li}$ et al. (2007) and Cao et al. (2008a) reported a very similar content of $\mathrm{K}^{+}$in $\mathrm{PM}_{2.5}$ emitted from agriculture residues: $9.94 \pm 11.8$ or $9.56 \pm 9.01(\mathrm{wt} \%)$ from wheat straw, and $11.38 \pm 8.49$ (wt $\%$ ) from rice straw. The 


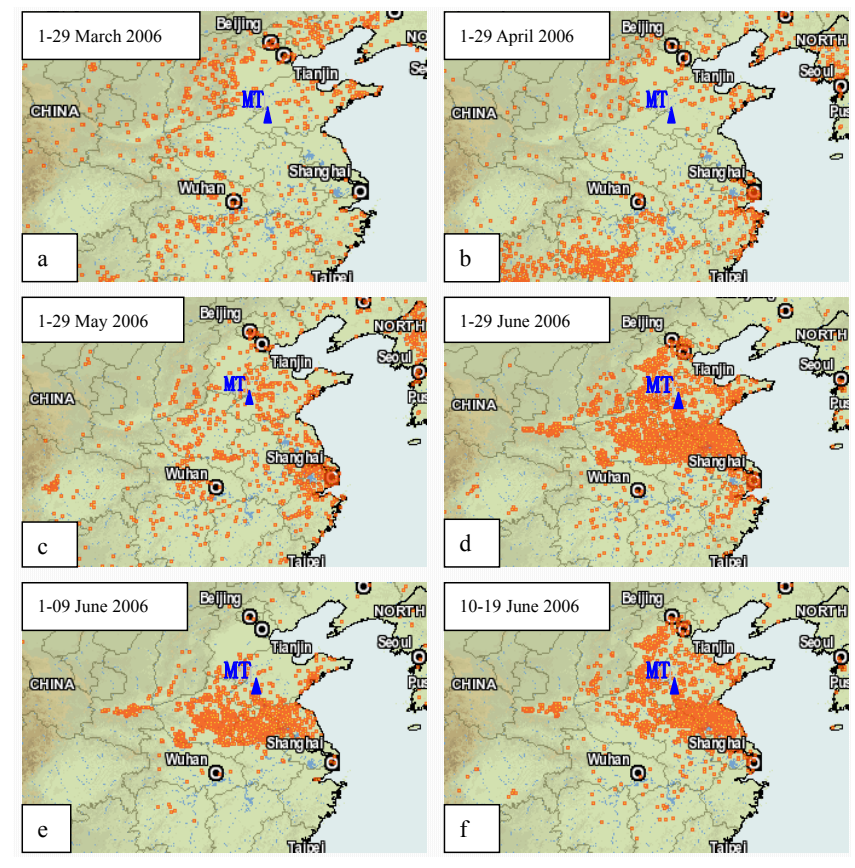

Fig. 7. Fire spot data derived from MODIS Global Fire Mapping during 2006: (a) 1-29 March, (b) 1-29 April, (c) 1-29 May, (d) 1-29 June, (e) 1-9 June and (f) 10-19 June at MT.

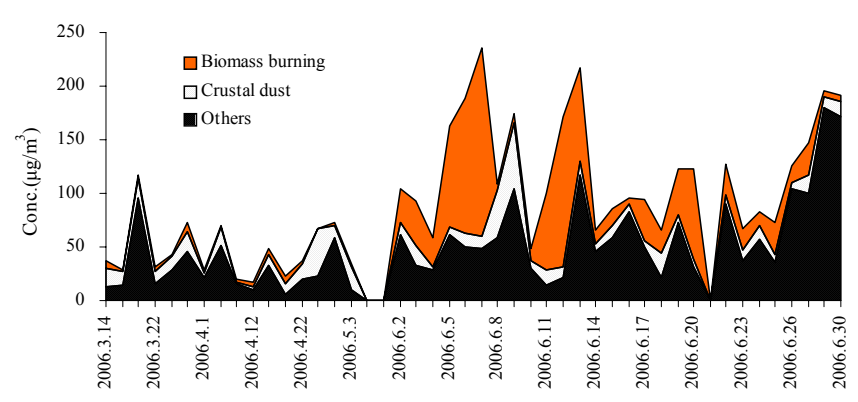

Fig. 8. Daily contributions of biomass burning, crustal dust, and others in $\mathrm{PM}_{2.5}$ at MT.

crustal dust-derived $\mathrm{PM}_{2.5}$ was calculated with the formula of $\mathrm{Al} / 0.08$. The results revealed that the contribution of biomass burning to the fine particle at MT accounted for $7.56 \%$ in spring and $36.71 \%$ in summer, and even reached to $81.58 \%$ on the day of 12 June. In addition, the concentrations of $\mathrm{K}^{+}$at different sampling sites are summarized in Table 8. The concentration of $\mathrm{K}^{+}$at MT was much higher than those at other sites, and it showed strong seasonal variation with $4.41 \mu \mathrm{g} \mathrm{m}^{-3}$ in summer and $0.48 \mu \mathrm{g} \mathrm{m}^{-3}$ in spring in $\mathrm{PM}_{2.5}$. Also, $\mathrm{K}^{+}$in $\mathrm{PM}_{2.5}$ correlated well to other species that are related to biomass burning, such as $\mathrm{BC}, \mathrm{C}_{2} \mathrm{O}_{4}^{2-}$, etc. (see Table 9). All of these results demonstrated evidently that biomass burning was one of major contributor to the aerosol pollution in summer over central eastern China, where MT is located.
Table 8. Concentrations of $\mathrm{K}^{+}$in $\mathrm{PM}_{2.5}$ at different sampling sites.

\begin{tabular}{llrrrr}
\hline Sites & Year & Spring & Summer & Autumn & Winter \\
\hline Shanghai & $2003-2004^{\mathrm{a}}$ & 0.73 & 0.46 & 0.39 & 1.79 \\
& 2005 & 0.53 & 0.29 & 0.97 & 0.70 \\
& 2006 & 0.57 & 0.32 & 2.39 & 1.30 \\
& 2007 & 0.30 & 0.50 & 1.11 & 0.94 \\
MT & 2006 & 0.48 & 4.41 & & \\
Urumqi & 2007 & 0.77 & 0.96 & 2.68 & 3.56 \\
Beijing & $2002^{\mathrm{b}}$ & 1.42 & 1.18 & & 2.80 \\
\hline
\end{tabular}

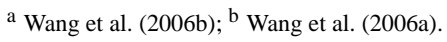
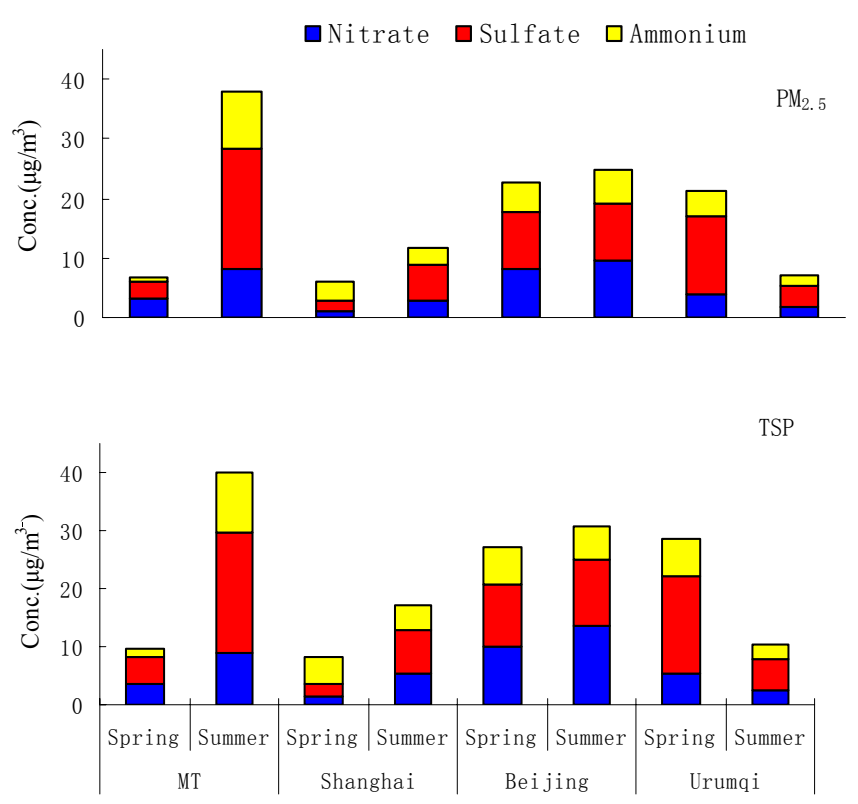

Fig. 9. Seasonal variations of $\mathrm{SO}_{4}^{2-}, \mathrm{NO}_{3}^{-}$, and $\mathrm{NH}_{4}^{+}$in aerosols at different sampling sites.

\subsubsection{Secondary components: $\mathrm{SO}_{4}^{2-}, \mathrm{NO}_{3}^{-}$, and $\mathrm{NH}_{4}^{+}$}

The concentrations of the main secondary species $\left(\mathrm{SO}_{4}^{2-}\right.$, $\mathrm{NO}_{3}^{-}$, and $\mathrm{NH}_{4}^{+}$) in aerosols in spring and summer of 2006/2007 at different sites (MT, Urumqi, Beijing, and Shanghai) are illustrated in Fig. 9. The results showed that these secondary ions in aerosols in summer at MT were $\sim 5$ times higher of those in spring, while there was no big change in Beijing, less change in Shanghai between the two seasons, and they were evidently greater in spring than those in summer at Urumqi. The sum of the three ions at MT in summer was higher than that at any other site, indicating much heavy secondary pollution at this region. Besides, at MT in summer the concentration of $\mathrm{SO}_{4}^{2-}$ was much greater than $\mathrm{NO}_{3}^{-}$, while in Beijing and Shanghai the concentrations of $\mathrm{NO}_{3}^{-}$was close to that of $\mathrm{SO}_{4}^{2-}$. Average concentrations of 
Table 9. Correlation coefficients between $\mathrm{K}^{+}$and other species in aerosols in summer at MT.

\begin{tabular}{lrrrrrrr}
\hline & $\mathrm{K}^{+}$ & $\mathrm{C}_{2} \mathrm{O}_{4}^{2-}$ & $\mathrm{BC}$ & $\mathrm{SO}_{4}^{2-}$ & $\mathrm{Cl}^{-}$ & $\mathrm{NO}_{3}^{-}$ & $\mathrm{NH}_{4}^{+}$ \\
\hline $\mathrm{K}^{+}$ & 1.000 & & & & & & \\
$\mathrm{C}_{2} \mathrm{O}_{4}^{2-}$ & 0.869 & 1.000 & & & & & \\
$\mathrm{BC}$ & 0.904 & 0.781 & 1.000 & & & & \\
$\mathrm{SO}_{4}^{2-}$ & 0.636 & 0.749 & 0.526 & 1.000 & & & \\
$\mathrm{Cl}^{-}$ & 0.708 & 0.640 & 0.742 & 0.481 & 1.000 & & \\
$\mathrm{NO}_{3}^{-}$ & 0.813 & 0.903 & 0.767 & 0.802 & 0.753 & 1.000 & \\
$\mathrm{NH}_{4}^{+}$ & 0.636 & 0.749 & 0.526 & 1.000 & 0.481 & 0.802 & 1.000 \\
\hline
\end{tabular}

$\mathrm{SO}_{4}^{2-}$ and $\mathrm{NO}_{3}^{-}$in TSP at MT were 4.47 and $3.61 \mu \mathrm{g} \mathrm{m}{ }^{-3}$ in spring, 20.73 and $8.82 \mu \mathrm{g} \mathrm{m}^{-3}$ in summer respectively, while in Shanghai 2.28 and $1.42 \mu \mathrm{g} \mathrm{m}^{-3}$ in spring, 7.34 and $5.50 \mathrm{\mu g} \mathrm{m}^{-3}$, in summer 2006, respectively. During the study period, the average concentrations of $\mathrm{SO}_{2}$ and $\mathrm{NO}_{2}$ were 46.0 and $24.0 \mu \mathrm{g} \mathrm{m}^{-3}$ in spring, 34.0 and $26.0 \mu \mathrm{g} \mathrm{m}^{-3}$ in summer over MT, while 51.0 and $41.0 \mu \mathrm{g} \mathrm{m}^{-3}$ in spring and 33.0 and $19.0 \mu \mathrm{g} \mathrm{m}^{-3}$ in summer in Shanghai. Mineral aerosols reacted with $\mathrm{SO}_{2}$ or $\mathrm{NO}_{2}$ to form a layer of sulfate or nitrate on the mineral surfaces through the heterogeneous reactions (Yaacov et al., 1989), and soil particles would be coated by solutions contained sulfate and nitrate. The reaction of $\mathrm{SO}_{2}$ on calcium-rich mineral aerosol was likely to play an important role in the downwind regions (Dentener et al., 1996), as many studies confirmed that the composition and morphology of dust particles would be changed during their transport (Underwood et al., 2001; Song et al., 2001). The conversion of $\mathrm{SO}_{2}$ and $\mathrm{NO}_{2}$ to be $\mathrm{SO}_{4}^{2-}$ and $\mathrm{NO}_{3}^{-}$in ambient air could be their major source in aerosols. Sulfur oxidation ratio (SOR) and nitrogen oxidation ratio (NOR) can indicate the efficiency of these transformations. If SOR is smaller than 0.10 , the $\mathrm{SO}_{4}^{2-}$ could be from the primary emissions (Pierson et al., 1979; Truex et al., 1980), otherwise, $\mathrm{SO}_{4}^{2-}$ was produced through the photochemical oxidation from $\mathrm{SO}_{2}$ (Ohta et al., 1990). Though concentrations of the gases were basically in the same levels, the SOR and NOR were significantly different between MT and Shanghai, especially in summer. SOR and NOR in TSP increased from 0.09 and 0.10 in spring to 0.32 and 0.26 in summer at MT, while 0.06 and 0.10 to 0.12 and 0.16 in Shanghai, respectively, in the same sampling time. This result indicated that in summer at MT the transformation efficiency of $\mathrm{SO}_{2}$ and $\mathrm{NO}_{2}$ to be $\mathrm{SO}_{4}^{2-}$ and $\mathrm{NO}_{3}^{-}$was much higher than that in Shanghai, and it would result in much higher concentrations of sulfate and nitrate at MT than that in Shanghai.

Many factors were likely attributed to the more effective conversion of $\mathrm{SO}_{2}$ and $\mathrm{NO}_{2}$ to be $\mathrm{SO}_{4}^{2-}$ and $\mathrm{NO}_{3}^{-}$on the summit of the mountain. Firstly, humidity plays a key role in the formation of sulfate from $\mathrm{SO}_{2}$, for $80-90 \%$ of the global sulfate was produced in the aqueous-phase, (Jill et al.,
2001). At the summit of MT, total cloud days were 5.4 and 7.0 in spring and summer, respectively, and monthly average foggy days could reach 26 , sometimes even 30 in summer, while only 10 in spring. The relatively high humidity at the summit in summer is in favor of the formation of sulfate. Secondary, oxidation of $\mathrm{SO}_{2}$ occurs potentially via three important pathways: oxidation by hydrogen peroxide or ozone, and auto-oxidation catalyzed by Fe (III) and $\mathrm{Mn}$ (II), and the former two were proved to be the dominative oxidation processes under certain conditions (Jill et al., 2001). High level of the biomass burning of agriculture residues resulted in increase of those gaseous pollutants, such as $\mathrm{O}_{3}$, $\mathrm{CO}$ and VOCs in summer. Averaged concentration of total peroxide $(0.55 \pm 0.67 \mathrm{ppbv})$ was significantly higher in summer than that $(0.17 \pm 0.26 \mathrm{ppbv})$ in spring at MT (Ren et al., 2009). The $\mathrm{O}_{3}$ in 2003 (Gao et al., 2005) and 2006 (Table 3) at MT showed that $\mathrm{O}_{3}$ was also higher in summer than that in spring. High levels of $\mathrm{O}_{3}$ and peroxide in ambient air in summer accelerated the conversion of $\mathrm{SO}_{2}$ and $\mathrm{NO}_{2}$ to be $\mathrm{SO}_{4}^{2-}$ and $\mathrm{NO}_{3}^{-}$. Lastly, at MT there is abundance of hydrocarbon emitted by the abundant foliage that covers more than $90 \%$ of the area of MT (Suthawaree, et al., 2010). $\mathrm{O}_{3}$ accelerated the formation of $\mathrm{SO}_{4}^{2-}$ by directly reacting with $\mathrm{SO}_{2}$ and generating $\mathrm{OH}$ radical that further to be transformed to peroxide via cooperating with hydrocarbon under light radiation. Hydrocarbon can react with $\mathrm{OH}$ radical to produce $\mathrm{HO}_{2}$ and $\mathrm{RO}_{2}\left(\mathrm{OH}+\mathrm{RH} \stackrel{\left[\mathrm{O}_{2}\right]}{\longrightarrow} \mathrm{RO}_{2}+\mathrm{H}_{2} \mathrm{O}, \mathrm{NO}+\mathrm{RO}_{2} \rightarrow \mathrm{RCHO}+\right.$ $\mathrm{HO}_{2}+\mathrm{NO}_{2}$ ) (Ariel et al., 2000), and $\mathrm{HO}_{2}$ further react with $\mathrm{SO}_{2}$ and $\mathrm{NO}_{2}$. Higher $\mathrm{CO}$ level produced from biomass burning in summer also contributed to the oxidation of $\mathrm{SO}_{2}$ by generating peroxide with $\mathrm{OH}$ radical $\left(\mathrm{OH}+\mathrm{CO} \stackrel{\left[\mathrm{O}_{2}\right]}{\longrightarrow} \mathrm{HO}_{2}+\mathrm{CO}_{2}\right)$. The reactive processes above would benefit the formation of organic acids: $\mathrm{HO}_{2}+\mathrm{RO}_{2} \rightarrow \mathrm{ROOH}+\mathrm{O}_{2}$. The high concentrations of diacids and the good correlations of diacids with $\mathrm{SO}_{4}^{2-}$, as shown in Fig. 10, further suggested the formation mechanism of high level of the secondary aerosol in summer at MT. Besides, $\mathrm{NH}_{4}^{+}$increased significantly from $1.48 \mu \mathrm{g} \mathrm{m}^{-3}$ in spring to $10.4 \mu \mathrm{g} \mathrm{m}^{-3}$ in summer, which was likely due to more pesticide sprayed in the large area of farming fields in late May and the stock-raise at MT region, which could produce much more $\mathrm{NH}_{3}$ in summer than in spring. Also, higher temperature in summer could lead to the higher emission of $\mathrm{NH}_{3}$ from animal's excrements (Sacoby et al., 2007).

\subsubsection{Mineral dust in spring time}

Concentrations of mineral elements (such as $\mathrm{Al}, \mathrm{Fe}$, and $\mathrm{Ca}$ ) are good indicators for crustal aerosols. Daily variation of mineral elements ( $\mathrm{Al}, \mathrm{Fe}$, and $\mathrm{Ca}$ ) at different sampling sites in spring, 2007 is shown in Fig. 11. It can be seen clearly that a strong dust storm occurred from 30 March to 2 April and resulted in sharp increase of the three mineral elements at all of these monitoring sites, especially at Tazhong, Yulin, 
Table 10. Ratio of $\mathrm{Ca} / \mathrm{Al}$ in aerosol or surface soil in different sampling sites over China.

\begin{tabular}{llll}
\hline Site & Type & $\mathrm{Ca} / \mathrm{Al}$ & Reference \\
\hline Tazhong (Taklimakan Desert) & $\mathrm{PM}_{2.5}$ & $1.55 \pm 0.22$ & This study \\
Yulin, China & $\mathrm{PM}_{2.5}$ & $0.52 \pm 0.43$ & This study \\
Duolun & $\mathrm{PM}_{2.5}$ & $0.45 \pm 0.12$ & This study \\
Beijing & $\mathrm{PM}_{2.5}$ & $1.37 \pm 0.39$ & This study \\
MT & $\mathrm{PM}_{2.5}$ & $1.37 \pm 0.22$ & This study \\
Taklimakan Desert & Aerosol & 1.99 & Zhang et al. (1996) \\
Badain Juran desert & Aerosol & 1.2 & Zhang et al. (1996) \\
Hunshandake sandland Soil & 0.52 & & Zhang et al. (1996) \\
Tongliao, Horqin sand land & $\mathrm{PM}_{2.5}$ & 0.76 & Shen et al. (2006) \\
Loess Plateau & Aerosol & 1.14 & Zhang et al. (2003) \\
& TSP & 1.22 & Cao et al. (2008b)
\end{tabular}
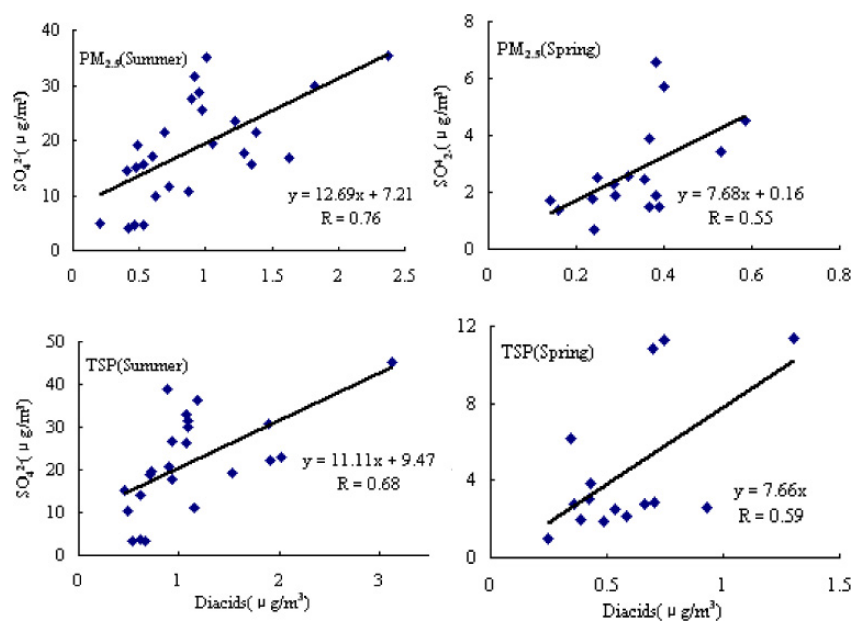

Fig. 10. Scatter plots of $\mathrm{SO}_{4}^{2-}$ vs. decides (sum of $\mathrm{CH}_{2} \mathrm{C}_{2} \mathrm{O}_{4}^{2-}$, $\mathrm{CH}_{4} \mathrm{C}_{2} \mathrm{O}_{4}^{2-}$, and $\mathrm{C}_{2} \mathrm{O}_{4}^{2-}$ ).

Duolun, MT, and Beijing. The ratio of $\mathrm{Ca} / \mathrm{Al}$ has been proved to be a good tracer for different dust original areas (Wang et al., 2005; Sun et al., 2005), for $\mathrm{Ca} / \mathrm{Al}$ showed remarkable dependence of the source regions for both dust aerosol and soil samples. Ratios of $\mathrm{Ca} / \mathrm{Al}$ in aerosol or soil from different sampling sites are shown in Table 10, and it could be seen clearly that Taklimakan desert, the western source of Asian dust, is characterized by high ratio of $\mathrm{Ca} / \mathrm{Al}$ of greater than 1.5, while the northern source of Asian dust, such as Duolun and Hunshandake Sandland, is characterized by low ratio of $\mathrm{Ca} / \mathrm{Al}$ of around 0.5 . The ratio of $\mathrm{Ca} / \mathrm{Al}(1.37 \pm 0.22)$ in the aerosol at MT indicated that the dust aerosol at MT in spring could be from the long-range transport of the dust from western or northwestern high-dust sources. The facts mentioned above that the coarse particles dominated in spring $\left(\mathrm{PM}_{2.5}\right.$ /TSP of 0.37$)$ and the alkalinity $(\mathrm{pH}=7.22)$ of the TSP in spring further confirmed that the long-range transport was the major source of the aerosols in spring at MT.
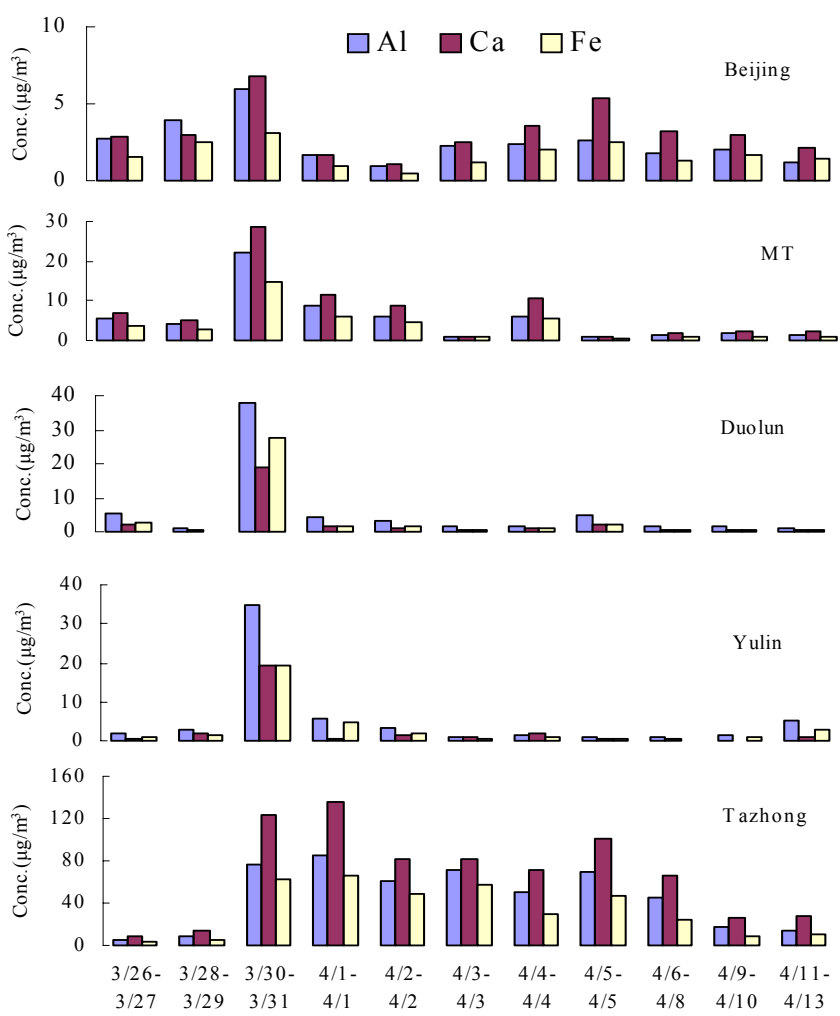

Fig. 11. Daily variation of mineral elements $(\mathrm{Ca}, \mathrm{Al}$ and $\mathrm{Fe})$ at different sampling sites in spring, 2007.

\subsubsection{The pollution elements $\mathrm{As}$ and $\mathrm{Pb}$}

The pollution elements, As and $\mathrm{Pb}$, were highly enriched in the aerosols with the EF of 1541 and 679, respectively, in spring, while 1470 and 1969 in summer in $\mathrm{PM}_{2.5}$ at MT. As and $\mathrm{Pb}$ were of different seasonal variations with summerhigh/spring-low of $\mathrm{Pb}$, while spring-high/summer-low of As. Correlation analysis (see Table 11 ) revealed that both $\mathrm{Pb}$ and As were highly correlated to those crustal elements in spring with the correlation coefficients of 0.701 for $\mathrm{Pb}$ to $\mathrm{Al}$ and 0.873 for $\mathrm{Pb}$ to $\mathrm{Fe}$, while of 0.837 for $\mathrm{As}$ to $\mathrm{Al}$ and 0.778 for As to Fe. Furthermore, the correlation coefficient between $\mathrm{Pb}$ and $\mathrm{As}$ was as high as 0.949. These results indicated that both $\mathrm{Pb}$ and As were highly associated with the mineral components, which was long-range transported from northwestern China to MT in spring. Those primary dust aerosols from northwestern China would mix with As and $\mathrm{Pb}$, which were emitted from coal-mining/coal-ash and widely distributed over northwestern China, and act as a carrier for $\mathrm{As}$ and $\mathrm{Pb}$. The pollution elements, $\mathrm{As}$ and $\mathrm{Pb}$, would gradually be enriched in the dust aerosol during its longrange transport. The results revealed that the long-range transport of aerosols spread the heavy pollution from coal burning everywhere over China. However, in summer the correlation coefficients of $\mathrm{Pb}$ to $\mathrm{Al}$ and $\mathrm{Pb}$ to $\mathrm{Fe}$ decreased 
Table 11. Correlation coefficients among the certain species in spring and summer at MT.

\begin{tabular}{|c|c|c|c|c|c|c|c|c|c|c|c|c|c|c|c|c|c|}
\hline & & $\mathrm{SO}_{4}^{2-}$ & $\mathrm{NO}_{3}^{-}$ & $\mathrm{BC}$ & $\mathrm{Al}$ & $\mathrm{Fe}$ & $\mathrm{Ca}$ & As & $\mathrm{Cr}$ & $\mathrm{Cu}$ & $\mathrm{Cd}$ & $\mathrm{Mn}$ & $\mathrm{Pb}$ & $\mathrm{Zn}$ & $\mathrm{Ti}$ & & \\
\hline \multirow{14}{*}{ 告 } & $\mathrm{SO}_{4}^{2-}$ & & .802 & .526 & .253 & .274 & .249 & .502 & .325 & .478 & .613 & .303 & .496 & .538 & -.243 & $\mathrm{SO}_{4}^{2-}$ & \\
\hline & $\mathrm{NO}_{3}^{-}$ & .954 & & .767 & .223 & .237 & .259 & .415 & .249 & .594 & .551 & .286 & .419 & .557 & -.087 & $\mathrm{NO}_{3}^{-}$ & \\
\hline & $\mathrm{BC}^{3}$ & .748 & .792 & & -.030 & -.029 & -.002 & .358 & .090 & .323 & .378 & .023 & .476 & .081 & .004 & $\mathrm{BC}^{3}$ & \\
\hline & $\mathrm{Al}$ & .225 & .185 & -.027 & & .997 & .986 & .469 & .795 & .623 & .691 & .984 & -.184 & .725 & .411 & $\mathrm{Al}$ & \\
\hline & $\mathrm{Fe}$ & .353 & .239 & -.070 & .781 & & .982 & .456 & .775 & .616 & .677 & .984 & -.194 & .733 & .390 & $\mathrm{Fe}$ & \\
\hline & $\mathrm{Ca}$ & .057 & .049 & -.241 & .857 & .806 & & .529 & .838 & .684 & .721 & .992 & -.139 & .755 & .482 & $\mathrm{Ca}$ & \\
\hline & As & .326 & .234 & -.061 & .837 & .778 & .683 & & .786 & .672 & .812 & .561 & .494 & .486 & .274 & As & $\cong$ \\
\hline & $\mathrm{Cr}$ & .164 & .111 & -.185 & .845 & .832 & .881 & .863 & & .785 & .847 & .855 & .148 & .704 & .372 & $\mathrm{Cr}$ & 忢 \\
\hline & $\mathrm{Cu}$ & .013 & -.043 & -.026 & .284 & .332 & .313 & .407 & .484 & & .802 & .700 & .337 & .825 & .308 & $\mathrm{Cu}$ & $\widetilde{\oplus}$ \\
\hline & $\mathrm{Cd}$ & .478 & .345 & .111 & .693 & .692 & .593 & .806 & .779 & .609 & & .754 & .527 & .720 & .204 & $\mathrm{Cd}$ & \\
\hline & $\mathrm{Mn}$ & .415 & .295 & -.004 & .815 & .963 & .805 & .764 & .851 & .320 & .782 & & -.092 & .770 & .447 & $\mathrm{Mn}$ & \\
\hline & $\mathrm{Pb}$ & .438 & .359 & .086 & .701 & .873 & .554 & .949 & .774 & .591 & .704 & .735 & & .134 & -.126 & $\mathrm{~Pb}$ & \\
\hline & $\mathrm{Zn}$ & .358 & .250 & .057 & .403 & .511 & .455 & .850 & .600 & .752 & .572 & .661 & .717 & & .105 & $\mathrm{Zn}$ & \\
\hline & $\mathrm{Ti}$ & .367 & .425 & -.051 & .763 & .749 & .793 & .687 & .809 & .354 & .994 & .960 & 679 & .599 & & $\mathrm{Ti}$ & \\
\hline
\end{tabular}

to -0.184 and -0.194 , while of $\mathrm{As}$ to $\mathrm{Al}$ and $\mathrm{As}$ to $\mathrm{Fe}$ to 0.469 and 0.456 , respectively, and the correlation coefficient between $\mathrm{Pb}$ and $\mathrm{As}$ decreased to 0.494 . These results indicated that in summer the source of $\mathrm{Pb}$ and As was not mainly from long-range transport, instead, they could be from those local/regional sources. It could be seen that $\mathrm{Pb}$ and $\mathrm{As}$ were both correlated well to $\mathrm{Cr}, \mathrm{Cu}$, and $\mathrm{Zn}$ in summer, suggesting that the source of $\mathrm{Pb}$ and $\mathrm{As}$ in summer would likely from the same local/reginal anthropogenic discharge as the pollution elements, $\mathrm{Cr}, \mathrm{Cu}$, and $\mathrm{Zn}$, did. The strong convections of air mass would result in the elevation to the summit of MT from the ground level of the pollutants. The emission of $\mathrm{Pb}$ from the local/regional anthropogenic source in summer could be much more than that from the long-range transport in spring, which led to the higher enrichment of $\mathrm{Pb}$ in summer than that in spring.

\section{Summary}

Aerosols over central eastern China showed significantly season variation, with fine particles dominated in summer while coarse particles in spring. The summit of MT was suffering from the invasion of long-range transported dust from northwestern China, the heavy local/regional anthropogenic emissions from the surrounding areas, and the severe secondary pollutions. The contribution of biomass burning to the fine particle at MT accounted for $7.56 \%$ in spring and $36.71 \%$ in summer, and even reached to $81.58 \%$ on a day. The high levels of peroxides and ozone, as well as the favourable meteorological conditions in the ambient air were in favour of the transformation of $\mathrm{SO}_{2}$ and $\mathrm{NO}_{\mathrm{x}}$ to sulfate and nitrate, which resulted in the even severe secondary pollution in this region. $\mathrm{As}$ and $\mathrm{Pb}$ were two of the most enriched elements. The long-range transport of aerosols spread the heavy pollution from coal-mining/coal-ash to everywhere over China. Anthropogenic air-pollution was evidently rather severe at MT.
Acknowledgements. This work was supported by the great international collaboration project of MOST, China (2010DFA92230), the National Key Project of Basic Research of China (Grant Nos. 2006CB403704), and National Natural Science Foundation of China (Grant Nos. 20877020, 20977017). The authors would like to acknowledge Zhihua Wang of Shangdong University for providing the data of $\mathrm{O}_{3}$ and $\mathrm{CO}$.

Edited by: S. C. Liu

\section{References}

Andreae, M. O.: Soot carbon and excess fine potassium: long-range transport of combustion-derived aerosols, Science, 220, 1148$1151,1983$.

Ariel, F. S. and Lamb, D.: The sensitivity of sulfer wet deposition to atmospheric oxidants, Atmos, Environ., 34, 1681-1690, 2000.

Arimoto, R.: Eolian dust and Climate: Relationship to sources, tropospheric chemistry, transport and deposition, Earth Sci. Rev., 54, 29-42, 2001.

Arimoto R., Duce R. A., and Savoie D. L.: Relationships among aerosol constituents from Asia and the North Pacific during PEM-West, J. Geophys. Res. Atmos., 101(D1), 2011-2023, 1996.

Cao, G., Zhang, X., Wang, D., and Zheng, F.: Inventory of atmospheric pollutants discharged from biomass burning in China continent, China Environ. Sci., 25(4), 389-393, 2005 (in Chinese).

Cao, G., Zhang, X., Wang, Y., and Zheng, F.: Estimation of the emission from open burning of crop residues in China continent, Chin. Sci. Bull., 52(18), 1826-1831, 2007 (in Chinese).

Cao, G., Zhang, X., Gong, S., and Zheng, F.: Investigation on emission factors of particulate matter and gaseous pollutants from crop residue burning, Environ. Sci., 20, 50-55, 2008a.

Cao, J. J., Chow, J. C., Watson, J. G., Wu, F., Han, Y. M., Jin, Z. D., Shen, Z. X., and An, Z. S.: Size-differentiated source profiles for fugitive dust in the Chinese Loess Plateau, Atmos. Environ., 42(10), 2261-2275, 2008b. 
Chan, Y. C., Simpson, R. W., Mctainsh, G. H., Vowles, P. D., Cohen, D. D., and Bailey, G. M.: Source apportionment of visibility degradation problems in Brisbane (Australia) using the multiple linear regression technique, Atmos. Environ., 33, 3237-3250, 1999.

Chester, R.: Marine Geochemistry, Unwin Hyman, London, 698 pp., 1990.

Dentener, F. J., Carmichael, G. R., and Zhang, Y.: Role of mineral aerosol as a reactive surface in the global troposphere, J. Geophys. Res. Atmos., 101(D17), 22869-22889, 1996.

Dockery, D. W., Pope, A. C., Xu, X., Spengler, J. D., Ware, J. H., Fay, M. E., Ferris Jr., B. G., and Speizer, F. E.: An association between air pollution and mortality in six US cities, New Engl. J. Med., 1753-1759, 1993.

Facchini, M. C. S., Decesari, M., Mircea, S., Fuzzi, and Loglio, G.: Surface tension of atmospheric wet aerosol and cloud/fog droplets in relation to their organic carbon content and chemical composition, Atmos. Environ., 34, 4853-4857, 2000.

Gao, J., Wang, T., Ding, A., and Liu, C.: Observational study of ozone and carbon monoxide at the summit of mount Tai (1534 m a.s.1.) in central-eastern China, Atmos. Environ., 39(20), 4779-4791, 2005.

Guo, J., Kenneth, A., Rahn, and Zhuang, G.: A mechanism for the increase of pollution elements in dust storms in Beijing, Atmos. Environ., 38, 855-862, 2004.

Han, L., Zhuang G., Sun Y., and Wang, Z. F.: Local and non-local sources of airborne particulate pollution at Beijing, Science in China Ser. B Chemistry, 48(4), 1-12, 2005.

Jill, E. R., Oliver, V. R., Katharine, F. M., Christopher J., Eli, D. S., Vincent, A. D., Sonia, M. K., Liaquat, H., and Collett Jr., J.: Drop size-dependent S (IV) oxidation in chemically heterogeneous radiation fogs, Atmos. Environ., 35, 5717-5728, 2001.

Kaufman, Y. J., Tanre, D., and Boucher, O.: A satellite view of aerosols in the climate system, Nature, 419, 215-223, 2002.

Li, X., Wang, S., Duan, L., Hao, J., Li, C., Chen, Y., and Yang, L.: Particulate and Trace Gas Emissions from Open Burning of Wheat Straw and Corn Stover in China, Environ. Sci. Technol., 41(17), 6052-6058, 2007.

Liu, C. L., Zhang, J., and Liu, S. M.: Physical and chemical characters of materials from several mineral aerosol sources in China, Environ. Sci., 23, 28-32, 2002.

Matsumoto, K., Tanaka, H., Nagao, I., and Ishizaka, Y.: Contribution of particulate sulfate and organic carbon to cloud condensation nuclei in the marine atmosphere, Geophys. Res. Lett., 24, 655-658, 1997.

Novakov, T. and Penner, J. E.: Large condensation of organic aerosols to cloud-condensation nuclei concentration, Nature, 365, 823-826, 1993.

Novelli, P. C., Masarie, K. A., Tans, P. P., and Lang, P. M.: Recent changes in atmospheric carbon monoxide, Science, 263, 15871590, 1994.

Novelli, P. C., Masarie, K. A., and Lang, P. M.: Distributions and recent changes of carbon monoxide in the lower troposphere, J. Geophys. Res., 103(D51), 19015-19033, 1998.

Ohta, S. and Okita, T.: A chemical characterization of atmospheric aerosol in Sapporo, Atmos. Environ., 24A, 815-822, 1990.

Pierson, W. R., Brachaczek, W. W., and Mckee, D. E.: Sulfate emissions from catalyst equipped automobiles on the highway, J. Air Pollut. Control Assoc., 29, 255-257, 1979.
Rastogi, N. and Sarin M. M.: Long-term characterization of ionic species in aerosols from urban and high altitude sites in western India: Role of mineral dust and anthropogenic sources, Atmos. Environ, 39, 5541-5554, 2005.

Rastogi, N. and Sarin, M. M.: Chemistry of aerosols over a semiarid region: Evidence for acid neutralization by mineral dust, J. Geophys. Res. Lett., 33, L23815, doi:10.1029/2006GL027708, 2006.

Ren, Y., Ding, A., Wang, T., Shen, X., Guo, J., Zhang, J., Wang, Y., Xu, P., Wang, X., Gao, J., Jeffrey, L., and Collett, J.: Measurement of gas-phase total peroxides at the summit of Mount Tai in China, Atmos. Environ., 43, 1702-1711, 2009.

Sacoby, M. W. and Marc, L.: Examination of atmospheric ammonia levels near hog CAFOs, homes, and schools in Eastern North Carolina, Atmos. Environ., 41, 4977-4987, 2007.

Shen, Z. X., Cao, J. J., Li, X. X., Wang, Y. Q., Jie, D. M., and Zhang, X. Y.: Chemical characteristics of aerosol particles $\left(\mathrm{PM}_{2.5}\right)$ at a site of Horqin Sand-land in northeast China, Environmental Sciences-China, 18(4), 701-707, 2006.

Song, C. H. and Carmichael, G. R.: A three-dimensional modeling investigation of the evolution processes of dust and sea-salt particles in East Asia, J. Geophys. Res.-Atmos., 106(D16), 1813118154, 2001.

Streets, D. G., Yarber, K. F., Woo, J. H., and Carmichael, G. R.: Biomass burning in Asia: Annual and seasonal estimates and atmospheric emissions, Global Biogeochem. Cy., 17(4), 1099, doi:10.1029/2003GB002040, 2003.

Sun, Y., Zhuang, G., Wang, Y., Han, L., Guo, J., Dan, M., Zhang, W., Wang, Z., and Hao, Z.: The air-borne particulate pollution in Beijing-concentration, composition, distribution and sources, Atmos. Environ., 38, 5991-6004, 2004.

Sun, Y., Zhuang, G., Wang, Y., Zhao, X., Li, J., Wang, Z., and An, Z.: Chemical composition of dust storms in Beijing and implications for the mixing of mineral aerosol with pollution aerosol on the pathway, J. Geophys. Res., 110, D24209, doi:10.1029/2005JD006054, 2005.

Sun, Y., Zhuang, G., Huang K., Li J., Wang, Q., Wang Y., Lin, Y., Fu, J., Zhang, W., Tang, A., and Zhao, X.: Asian dust over northern China and its impact on the downstream aerosol chemistry in 2004, J. Geophys. Res., 115, D00K09, doi:10.1029/2009JD012757, 2010.

Suthawaree, J., Kato, S., Okuzawa, K., Kanaya, Y., Pochanart, P., Akimoto, H., Wang, Z., and Kajii, Y.: Measurements of volatile organic compounds in the middle of Central East China during Mount Tai Experiment 2006 (MTX2006): observation of regional background and impact of biomass burning, Atmos. Chem. Phys., 10, 1269-1285, doi:10.5194/acp-10-1269-2010, 2010.

Tegen, I., Lacis, A. A., and Fung, I.: The influence of climate forcing of mineral aerosols from disturbed soils, Nature, 380(4), 419-422, 1996.

Truex, T. J., Pierson, W. R., and Mckee, D. E.: Sulfate in diesel exhaust. Environ. Sci. Technol., 14, 1118-1121, 1980.

Tsai, Y. I. and Cheng, M. T.: Visibility and aerosol chemical compositions near the coastal area in central Taiwan, Sci. Total Environ., 231, 37-51, 1999.

Underwood, G. M., Li, P., Al-Abadleh, H., and Grassian, V. H.: A Knudsen cell study of the heterogeneous reactivity of nitric acid on oxide and mineral dust particles, J. Phys. Chem. A., 105(27), 
6609-6620, 2001.

Virkkula, A., Teinilä, K., Hillamo, R., Kerminen, V.-M., Saarikoski, S., Aurela, M., Viidanoja, J., Paatero, J., Koponen, I. K., and Kulmala, M.: Chemical composition of boundary layer aerosol over the Atlantic Ocean and at an Antarctic site, Atmos. Chem. Phys., 6, 3407-3421, doi:10.5194/acp-6-3407-2006, 2006.

Wang, T., Cheung, A., Vincent, T. F., Anson, M., and Li, Y. S.: Ozone and related gaseous pollutants in the boundary layer of eastern China: overview of the recent measurements at a rural site, Geophys. Res. Lett., 28(12), 2373-2376, 2001.

Wang, Y., Zhuang, G., Sun, Y., and An, Z.: Water-soluble part of the aerosol in the dust storm season - evidence of the mixing between mineral and pollution aerosols, Atmos. Environ., 39, 7020-7029, 2005.

Wang, Y., Zhuang, G., Sun Y., and An, Z.: The variation of characteristics and formation mechanisms of aerosols in dust, haze, and clear days in Beijing, Atmos. Environ., 40, 6579-6591, $2006 \mathrm{a}$.

Wang, Y., Zhuang, G., Zhang, X., Huang, K., Xu, C., Tang, A., Chen, J., and An, Z.: The ion chemistry, seasonal cycle, and sources of $\mathrm{PM}_{2.5}$ and TSP aerosol in Shanghai, Atmos. Environ., 40, 2935-2952, 2006b.

Wang, Y., Ge, F., Liu, X., Wang, W., Jia, H., and Wang, D.: Analysis of the ionic characteristics for wet droplets at Mountain Tai, China Environ. Sci., 26(4), 422-426, 2006c (in Chinese).

Wang, Y., Wai, K., Gao, J., Liu, X., Wang, T., and Wang, W.: The impacts of anthropogenic emissions on the precipitation chemistry at an elevated site in North-eastern China, Atmos. Environ., 42, 2959-2970, 2008.
Wedepohl, K. H.: The compositions of the continental crust, Geochim. Cosmochim. Acta, 59, 1217-1232, 1995.

Yaacov, M. and Judith, G.: Heterogeneous reactions of minerals with sulfur and nitrogen oxides, J. Aerosol Sci., 20(3), 303-311, 1989.

Yuan, H., Wang, Y., and Zhuang, G.: The simultaneous determination of organic acid, MSA with inorganic anions in aerosol and rainwater by ion chromatography, J. Inst. Anal., 6, 12-16, 2003 (in Chinese).

Zhang, X. Y., Zhuang, G. Y., Zhu, G. H., Zhang, D., An, Z. S., Chen, T., and Huang, X. P.: Element tracers for Chinese source dust, Science in China (Series D), 39(5), 512-521, 1996.

Zhang, X. Y., Arimoto, R., and An, Z. S.: Dust emission from Chinese desert sources linked to variations in atmospheric circulation, J. Geophys. Res.-Atmos., 102(D23), 28041-28047, 1997.

Zhang, D., Zang, J., Shi, G., Iwasaka, Y., Matsuki, A., and Trochkine, D.: Mixture state of individual Asian dust particles at a coastal site of Qingdao, China, Atmos. Environ., 37(28), 38953901, 2003.

Zhu, B., Zhu, X., Zhang, Y., Zeng, L., and Zhang, Y.: Emission factors of $\mathrm{PM}_{2.5}$ from crop straw burning, Res. Environ. Sci., 18(2), 29-33, 2005 (in Chinese).

Zhuang, G., Guo, J., Yuan, H., and Zhao, C.: The compositions, sources, and size distribution of the dust storm from China in spring of 2000 and its impact on the global environment, Chin. Sci. Bull., 46(11), 895-900, doi:10.1007/BF02900460, 2001. 